\title{
Arctic cephalopod distributions and their associated predators
}

\author{
Kathleen Gardiner \& Terry A. Dick \\ Biological Sciences, University of Manitoba, Winnipeg, Manitoba R3T 2N2, Canada
}

\section{Keywords}

Arctic Ocean; Canada; cephalopods;

distributions; oceanography; predators.

\section{Correspondence}

Terry A. Dick, Biological Sciences, University of Manitoba, Winnipeg, Manitoba R3T 2N2, Canada. E-mail: tadick@cc.umanitoba.ca

doi:10.1111/j.1751-8369.2010.00146.x

\begin{abstract}
Cephalopods are key species of the eastern Arctic marine food web, both as prey and predator. Their presence in the diets of Arctic fish, birds and mammals illustrates their trophic importance. There has been considerable research on cephalopods (primarily Gonatus fabricii) from the north Atlantic and the west side of Greenland, where they are considered a potential fishery and are taken as a by-catch. By contrast, data on the biogeography of Arctic cephalopods are still incomplete. This study integrates most known locations of Arctic cephalopods in an attempt to locate potential areas of interest for cephalopods, and the predators that feed on them. International and national databases, museum collections, government reports, published articles and personal communications were used to develop distribution maps. Species common to the Canadian Arctic include: G. fabricii, Rossia moelleri, R. palpebrosa and Bathypolypus arcticus. Cirroteuthis muelleri is abundant in the waters off Alaska, Davis Strait and Baffin Bay. Although distribution data are still incomplete, groupings of cephalopods were found in some areas that may be correlated with oceanographic variables. Understanding species distributions and their interactions within the ecosystem is important to the study of a warming Arctic Ocean and the selection of marine protected areas.
\end{abstract}

Cephalopods are found in all marine habitats of the world, and are prey for a variety of commercial and culturally significant species. Cephalopod distributions are correlated (Hjort \& Ruud 1929; Bjørke 2001) with predators such as narwhals (Monodon monoceros L.) (e.g., Finley \& Gibb 1982; Bjørke 2001) and Greenland halibut (Reinhardtius hippoglossoides Walbaum) (e.g., Orr \& Bowering 1997; Dawe et al. 1998; Bjørke 2001). A species of interest is the squid Gonatus fabricii Lichtenstein, which is considered a keystone species in several Arctic food webs (Chambers \& Dick 2007). Gonatus fabricii are high in lipids and an excellent source of energy (Hooker et al. 2001; Frandsen \& Wieland 2004). These squid are also predatory on a variety of fish and other marine invertebrates (e.g., Nesis 1965), enabling a transfer of energy from the productive epipelagic zone to benthic waters through ontogenetic migrations (Sennikov et al. 1989).

A significant body of research has been conducted on cephalopods around Greenland (e.g., Collins 2002; Zumholz \& Frandsen 2006), Norwegian (Kristensen 1977; Wiborg et al. 1982) and Russian waters (e.g., Nesis 1965, 2001). However, cephalopods of the Canadian Arctic (above $60^{\circ} \mathrm{N}$ ) are not well known. Most reports (e.g., Clarke 1966; Kristensen 1983; O’Dor \& Macalaster 1983; Nesis 2001) have focused on potential commercial species (e.g., G. fabricii) and their presence or absence in an area, whereas others have been general surveys.

The objectives of this work are to: (1) consolidate all distributional data to a single source; (2) present maps to identify areas of biodiversity interest and potential feeding areas (i.e., predator-prey interactions); and (3) establish a baseline for future comparisons, including climate change effects in the Arctic.

\section{Materials and methods}

Initial queries into Arctic cephalopods were conducted using the Global Biodiversity Information Facility website (http://www.gbif.org/). All cephalopod records for areas north of $60^{\circ} \mathrm{N}$ were acquired, and five taxa were determined to be the most abundant. Of those taxa, records were obtained through contacts with museums (the Canadian Museum of Nature [CMNML] in Ottawa, Ontario, and the Atlantic Reference Centre [ARC] in St. Andrew's, New Brunswick), organizations such as Arctic Ocean Diversity (ArcOD, at the University of Alaska 
Table 1 Additional reported cephalopod species from the circumpolar Arctic.

\begin{tabular}{|c|c|}
\hline Species & Locations \\
\hline Architeuthis sp. ${ }^{\mathrm{a}, \mathrm{b}, \mathrm{c}}$ & Iceland, Norwegian coast, south-west Greenland \\
\hline Bathypolypus sp. d,e,f & Baffin Bay, Hudson Strait, south-west Greenland \\
\hline Bathypolypus bairdiid, ${ }^{\mathrm{e}, \mathrm{g}, \mathrm{h}}$ & $\begin{array}{l}\text { Baffin Bay, Davis Strait, Denmark Strait, east Greenland, south-west Greenland, Iceland, Norwegian coast, south } \\
\text { of Svalbard }\end{array}$ \\
\hline Bathypolypus pugniger sp..$^{\text {e, h }}$ & Baffin Bay, Denmark Strait, Faroe Islands, Iceland, south-west Greenland \\
\hline Benthoctopus sp. ${ }^{b, i, j, k}$ & Faroe-Shetland Strait, Kara Sea, Norwegian coast, Resolute Bay (Nunavut), east Svalbard \\
\hline Benthoctopus hokkaidensis' & Point Barrow, Alaska \\
\hline Benthoctopus profundorum' & Point Barrow, Alaska \\
\hline Benthoctopus sibericus ${ }^{\mathrm{b}, \mathrm{j}}$ & east Siberian and Laptev seas \\
\hline Brachioteuthis riiseib & Faroe Islands, Norwegian coast, Norwegian Sea, south Iceland \\
\hline Eledone cirrhosa $a^{\mathrm{b}, \mathrm{m}}$ & Iceland, Norwegian coast, Norwegian sea, Svalbard \\
\hline Gonatus sp. d,e,f,i,n,o & $\begin{array}{l}\text { Baffin Bay, east Baffin Island, Cumberland Strait (mouth), Foxe Basin, southern tip of Greenland, south-west } \\
\text { Greenland, Hudson Strait, Point Barrow (Alaska) }\end{array}$ \\
\hline Graneledone verrucosa ${ }^{b}$ & south of Iceland \\
\hline Grimpoteuthis sp.,p & Denmark Strait \\
\hline Illex illecebrosus ${ }^{\mathrm{a}, \mathrm{b}}$ & south Greenland (Frederikshaab), Iceland \\
\hline Loligo forbesiiq,r & North Sea, Norwegian coast, Norwegian Sea \\
\hline Moroteuthis robusta & Gulf of Alaska \\
\hline Ommastrephes bartrami ${ }^{b}$ & north-east Greenland, Norwegian Sea \\
\hline Onychoteuthis banskib & south of Iceland, north coast of Norway \\
\hline Opisthoteuthis sp..$^{\mathrm{t}, \mathrm{u}}$ & Davis Strait, Gulf of Alaska, south Iceland \\
\hline Opisthoteuthis borealis ${ }^{v}$ & south-west Greenland, south Iceland \\
\hline Rossia sp. e,f,w $^{2}$ & Baffin Bay, Denmark Strait, Hudson Strait, north Somerset Island (Nunavut) \\
\hline Rossia glaucopis $s^{\mathrm{b}, \mathrm{g}, \mathrm{m}, \mathrm{n}, \mathrm{q}, \mathrm{r}, \mathrm{x}}$ & Barents Sea, around the Faroe Islands, east Greenland, Kara Sea, Iceland, North Sea, Svalbard \\
\hline Rossia macrosoma ${ }^{b}$ & Faroe Islands, Norwegian coast \\
\hline Rossia megaptera ${ }^{a, y}$ & Davis Strait \\
\hline Semirossia tenera ${ }^{\mathrm{b}}$ & Laptev Sea, Norwegian coast \\
\hline Sepiola atlanticab,m & south of Iceland, Iceland \\
\hline Sepiola rondelettiy & Ellesmere Island, Jones Sound \\
\hline Stauroteuthis syrtensis ${ }^{\mathrm{t}}$ & Davis Strait, Denmark Strait \\
\hline Teuthowenia megalops $s^{\mathrm{b}, \mathrm{g}, \mathrm{i}, \mathrm{z}}$ & Denmark Strait, south-west Greenland, south Iceland \\
\hline Todarodes sagittatus ${ }^{\mathrm{b}, \mathrm{m}}$ & Faroe Islands, Iceland, north coast of Norway \\
\hline Todaropsis elbanae $e^{\text {aa }}$ & North Sea, Norway \\
\hline
\end{tabular}

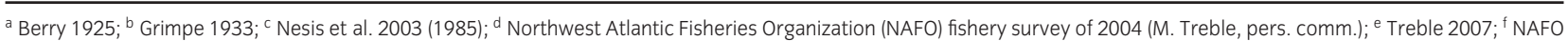
survey of 2007 (M. Treble, pers. comm.); ${ }^{8}$ Muus 1962; ${ }^{h}$ Muus 2002; i Smithsonian National Museum of Natural History Invertebrate Zoology Collections; i Nesis 2001; ${ }^{k}$ Muus (2002) reported that the Benthoctopus type specimen is actually a Bathypolypus spp. Therefore any mention of Benthoctopus piscatorum has been listed as Benthoctopus sp.; ${ }^{\prime}$ Mercer 1968; ${ }^{\mathrm{m}}$ Taxonomic Information System for the Belgian Coastal Area database; ${ }^{\mathrm{n}}$ Atlantic Reference Centre database; ${ }^{\circ}$ Piatkowski \& Wieland $1993 ;{ }^{p}$ Referred to in this article as Opisthoteuthis megaptera, an invalid species name according to the Integrated Taxonomic Information System (2008); ${ }^{9}$ Historical Benthic Dredge Samples from the Southern Baltic and the North Sea database; ${ }^{r}$ Kondakov 1937; ${ }^{5}$ North Pacific Groundfish Observer database; ${ }^{t}$ Collins 2002; ${ }^{u}$ Nesis 2003 (1989); ${ }^{v}$ Collins 2005; w D. Hardie (pers. comm. 2007); ${ }^{x}$ Atlantic Reference Centre; ${ }^{y}$ Academy of Natural Sciences Malacology Database; ${ }^{z}$ Nesis 1965 ; a ${ }^{2}$ Swedish Museum of Natural History: Invertebrates database.

Fairbanks) and the US National Oceanic and Atmospheric Administration (NOAA) Ocean Explorer project, and unpublished data of one of the authors (TAD) as well as unpublished data provided in 2007 by L. Harwood, B. Bluhm and D. Hardie. Data and locations were also obtained from published literature (e.g., Wiborg et al. 1982; Nesis 2001; Muus 2002; Raskoff et al. in press). The GeoNames website was used to determine the most likely latitude and longitude in lieu of the given place name. All samples listed from Arctic communities were assumed to be caught at the nearest marine location. Additional locations were identified from published, geo-referenced maps (Nesis 1965; Kristensen 1977, 1982; Wiborg et al. 1982; Sennikov et al. 1989). If the identification from a location was questionable (e.g., fishery survey) the specimens were listed as unidentified. If a specimen was described from a broad region (e.g., bay, sea, ocean), it was not mapped but was listed in Table 1. Specific sites were averaged from start and end trawl locations. Sample numbers were denoted with incrementally larger markers.

All specimens from the Northwest Atlantic Fisheries Organization (NAFO) fishery survey of 2007 (M. Treble, pers. comm.) were identified by one of the authors (KG). Specimens from the CMNML collection from Frobisher Bay (CMNML 35058) and Cape Parry (CMNML 37887, $37897,37891)$ were examined to verify the original identification, and were found to be correct. The identification of ARC specimens, primarily from the Mercer collection, 
Table 2 Percentages of cephalopod prey items reported from the stomachs of Arctic predators.

\begin{tabular}{|c|c|c|c|}
\hline Location & Predators & Cephalopod prey & $\%$ of diet (weight) \\
\hline \multirow[t]{17}{*}{ Bering Sea } & Baird's beaked whale (Berardius bairdii) ${ }^{a}$ & cephalopods & $90 \%$ \\
\hline & bearded seals (Erignathus barbatus) ${ }^{\mathrm{a}}$ & octopods & $<1 \%$ \\
\hline & beluga whale (Delphinapterus leucas) ${ }^{\mathrm{a}}$ & cephalopods & $2 \%$ \\
\hline & Bering Sea beaked whale (Mesoplodon stejnegeri) ${ }^{a}$ & cephalopods & $90 \%$ \\
\hline & Dall's porpoise (Phocoenoides dalli) a & squid & $50 \%$ \\
\hline & fin whale (Balaenoptera physalus) ${ }^{a}$ & cephalopods & $2 \%$ \\
\hline & harbour porpoise (Phocoena phocoena) ${ }^{\mathrm{a}}$ & squid & $1 \%$ \\
\hline & harbour seal (Phoca vitulina) ${ }^{\mathrm{a}}$ & squid & $4 \%$ \\
\hline & humpback whale (Megaptera novaeangliae) ${ }^{a}$ & cephalopods & $1 \%$ \\
\hline & killer whale $(O r c i n u s \text { orca })^{\mathrm{a}}$ & cephalopods & $20 \%$ \\
\hline & minke whale (Balaenoptera acutorostrata) ${ }^{a}$ & cephalopods & $1 \%$ \\
\hline & northern fur seal (Callorhinus ursinus) ${ }^{\mathrm{a}}$ & squid & $33 \%$ \\
\hline & northern sea lion (Eumetopias jubatus) a & squid & $3 \%$ \\
\hline & Pacific walrus (Odobenus rosmarus) $)^{a}$ & octopods & $1 \%$ \\
\hline & ribbon seal (Histriophoca fasciata) & squid & $1 \%$ \\
\hline & sperm whale (Physeter macrocephalus) ${ }^{a}$ & cephalopods & $82 \%$ \\
\hline & spotted seal (Phoca largha) ${ }^{a}$ & squid & $<1 \%$ \\
\hline \multirow[t]{2}{*}{ Bjørnøya and Bleiksøy islands } & thick-billed murre (Uria lomvia) ${ }^{b}$ & squid & $30 \%$ \\
\hline & common murre (Uria aalge $)^{b}$ & Gonatus fabricii & $40 \%$ \\
\hline \multirow[t]{2}{*}{ Clyde } & bearded seal (Erignathus barbatus) ${ }^{c, d}$ & Bathypolypus arcticus & $<1 \%$ \\
\hline & & Gonatus sp. & $<1 \%$ \\
\hline \multirow[t]{2}{*}{ Grise Fjord } & bearded seal (Erignathus barbatus) ${ }^{c, e}$ & Bathypolypus arcticus & $<1 \%$ \\
\hline & & Gonatus sp. & $<1 \%$ \\
\hline Iceland & hooded seal (Cystophora cristata) ${ }^{\dagger}$ & Gonatus sp. & $79 \%$ \\
\hline \multirow[t]{5}{*}{ Norwegian waters } & sperm whale (Physeter macrocephalus) ${ }^{g}$ & Gonatus sp. & $96 \%$ \\
\hline & & Haliphron & $1.60 \%$ \\
\hline & & Histioteuthis & $1.20 \%$ \\
\hline & & Teuthowenia & $0.34 \%$ \\
\hline & & Todarodes & $0.43 \%$ \\
\hline \multirow[t]{3}{*}{ eastern Norwegian waters } & sperm whale (Physeter macrocephalus) ${ }^{\dagger}$ & Cranchiidae & $25 \%$ \\
\hline & & Gonatus sp. & $9 \%$ \\
\hline & & Histioteuthis & $38 \%$ \\
\hline \multirow[t]{3}{*}{ Pond Inlet } & bearded seal (Erignathus barbatus), ${ }^{c, h}$ & Bathypolypus arcticus & $<1 \%$ \\
\hline & & Gonatus sp. & $<1 \%$ \\
\hline & narwhal (Monodon monoceros) $)^{\mathrm{i}, \mathrm{j}, \mathrm{k}}$ & squid & $<5 \%$ \\
\hline
\end{tabular}

a Perez 1990; ${ }^{b}$ Barrett et al. 1997; c Finley \& Evans 1983; ${ }^{d}$ Finley \& Evans (1983) reported that bearded seals from the Clyde had a $57 \%$ occurrence of B. arcticus and Gonatus $\mathrm{sp}$. in their stomachs. ${ }^{e}$ Finley \& Evans (1983) also reported bearded seals from Grise Fjord, NU, had a 67\% occurrence of B. arcticus and a $71 \%$ occurrence of Gonatus sp. in their stomachs. ${ }^{\dagger}$ Bjørke 2001; g Santos et al. 2001; h Finley \& Evans (1983) described an occurrence of $85 \%$ B. arcticus and $77 \%$ Gonatus sp. in the stomachs of bearded seals caught off Pond Inlet, NU. ' Finley \& Gibb 1982; ' Estimates from Pond Inlet in 1978 described a $92 \%$ occurrence of G. fabricii and a $16 \%$ occurrence of B. arcticus in the stomachs of narwhals caught. In 1979, $79 \%$ of narwhals had G. fabricii and $17 \%$ had B. arcticus remains in their stomachs (Finley \& Gibb 1982). ${ }^{k}$ Finley \& Gibb (1982) reported that narwhals in Pond Inlet were feeding on cephalopods, in particular, G. fabricii.

was previously verified by the senior author. Although location data were only used from reputable sources, there is the chance of mis-identifications, especially with Bathypolypus arcticus Prosch. Holdings of this particular species should be re-examined to verify its speciation. The names of all species were validated, and those considered invalid were listed as their synonym in accordance with the Integrated Taxonomic Information System.

Beaks and specimens from stomach content analyses were recorded as such in the data set. Locations were obtained from published literature, government documents, surveys, Arctic expeditions (e.g., Wacasey et al. 1979; Nesis 2001; Cephbase) and unpublished data (T.A.
Dick; L. Harwood, pers. comm. 2007) (Tables 1-4). Each predator species was identified with a unique symbol that differed from specimens recovered from trawls. Again, if a location was described from a broad region, it was not mapped. Predators and capture locations are listed in Tables 2-4.

All locations were mapped using ARCMAP 9 (ESRI GIS mapping software).

\section{Results}

Specimens described in this paper were collected between 1856 and 2007. The five most prominent species from the 
Table 3 Percentage occurrences of cephalopod prey items from the stomachs of Arctic predators (percentages of predators sampled with cephalopods in their stomachs).

\begin{tabular}{|c|c|c|c|}
\hline Location & Predators & Cephalopod prey & $\begin{array}{l}\text { \% occurrence } \\
\text { in stomachs }\end{array}$ \\
\hline Andenes & sperm whale (Physeter macrocephalus) ${ }^{a}$ & squid & 83.3 \\
\hline Barrow (Alaska) & bearded seal (Erignathus barbatus) ${ }^{c}$ & Octopus spp. & 69.4 \\
\hline Barrow (Alaska), Holman (Canada) & ringed seal (Pusa hispida) ${ }^{c}$ & cephalopods & 2.6 \\
\hline Davis Strait & Greenland halibut (Reinhardtius hippoglossoides) ${ }^{\mathrm{d}, \mathrm{e}}$ & cephalopods & 2 \\
\hline \multirow[t]{2}{*}{ Greenland Sea pack ice } & harp seal (Phoca groenlandica $)^{f}$ & Gonatus sp. & 40 \\
\hline & hooded seal (Cystophora cristata $)^{\dagger}$ & Gonatus sp. & 82 \\
\hline Hendrickson Island & beluga whale (Delphinapterus leucas)g & cephalopods & 3 \\
\hline Jan Mayen & northern bottlenose whale (Hyperoodon ampullatus) a & cephalopods & 75 \\
\hline Kendall Island Bird Sanctuary & beluga whale (Delphinapterus leucas)g & cephalopods & 3 \\
\hline Little Diomede Island (Alaska) & spotted seal (Phoca largha) ${ }^{c}$ & squid & 2.6 \\
\hline north-east Iceland & northern bottlenose whale (Hyperoodon ampullatus) ${ }^{a}$ & Gonatus sp. & 100 \\
\hline
\end{tabular}

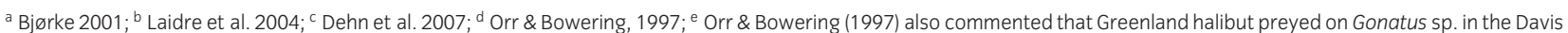
Strait; ${ }^{\dagger}$ Haug et al. 2004; ${ }^{g}$ L. Harwood (pers. comm. 2007).

Canadian Arctic are G. fabricii, Rossia moelleri Steenstrup, R. palpebrosa Owen, B. arcticus and Cirroteuthis muelleri Eschricht.

\section{Gonatus fabricii distribution}

Gonatus fabricii has a circumpolar distribution, extending from Alaska north to the high Arctic (Fig. 1). The Canadian range extends from the Dolphin and Union Strait, Northwest Territories (NWT), north to Cape Vera, Nunavut (NU), and Pond Inlet, NU, and south through the Hudson Strait (Fig. 1). G. fabricii also extends along the coasts of Greenland, through the Denmark Strait, Norwegian Sea, off the Norwegian shore, around the Faroe Islands and Svalbard, and into the Barents Sea (Figs. 1, 2).

Because of the number of groundfish and shrimp surveys in the Norwegian Sea and west coast of Greenland, there are numerous records of G. fabricii (Nesis 1965; Kristensen 1977; Wiborg et al. 1982; Sennikov et al. 1989). Other areas of interest include Cape Vera (190 specimens) and Pond Inlet (46 specimens) (Figs. 1, 2). Wiborg et al. (1982) also identified potential spawning sites in the Norwegian Sea (Fig. 2).

Distributions around Greenland and Hudson Strait are based on samples collected in trawls, whereas those from Cape Vera and Pond Inlet are from stomach contents of northern fulmars (Fulmarus glacialis L.) and narwhals, respectively (Fig. 3). Several Hudson Strait locations are from the stomachs of thick-billed murres (Uria lomvia L.), whereas most of the locations in the eastern Arctic are based on stomach contents from commercially fished haddock (Melanogrammus aeglefinus L.), Greenland halibut and cod (Gadus sp. L.) (Fig. 3).

\section{Rossia moelleri distribution}

Rossia moelleri has a circumpolar distribution, with a range extending from Cape Parry, NWT, through the Dolphin and Union Strait, NWT, to Foxe Basin, Frobisher Bay and north to Slidre Fjord, Ellesmere Island (Fig. 4). It was also recorded from western Greenland and Denmark Strait (Fig. 4). There are records from the Norwegian Sea north to Svalbard, with one specimen reported from the Laptev Sea (Fig. 4).

Cape Parry (12 records) and Slidre Fjord (nine records) have the greatest number of recorded specimens (Fig. 4).

Most records are from trawls. One beak was collected from a walrus (Odobenus rosmarus L.) off the north-west tip of Greenland (Fig. 5). Records from the Norwegian Sea and Denmark Strait are primarily from the stomachs of cod. One was from the stomach of a haddock (Fig. 5).

\section{Rossia palpebrosa distribution}

Most records of $R$. palpebrosa are reported from the junction of the East Siberian and Laptev seas and the Laptev Sea proper (Fig. 6). Individuals were recorded from Svalbard, the Kara and Barents seas, as well as from the northern tip of Greenland to Disko Bay, across Davis to the Hudson Strait (Fig. 6). Individuals were also collected from Slidre Fjord, Ellesmere Island, Frobisher Bay and the east coast of Somerset Island (Fig. 6).

There are no records of predators for this species.

\section{Bathypolypus arcticus distribution}

The Arctic range of B. arcticus extends from Frobisher Bay north through Davis Strait to Pond Inlet, Devon Island 
Table 4 Anecdotal accounts of cephalopods as prey species from the Arctic.

Location
Admiralty Inlet
Akpatok Island
Arctic/sub-Arctic waters of North America
Atlantic side of Arctic
Barents Sea
Barrow (Alaska)
Barrow (Alaska), Holman (Canada)
Barrow Strait
Canadian Arctic
Coats Island
Digges Island
east coast of Greenland, Denmark Strait
eastern Bering Sea

Eclipse Sound

Greenland

Hantzsch Island

High Arctic

Iceland-Faroe Ridge

Irminger Sea, south Iceland

Lancaster Sound

Navy Board Inlet

northern Bering and Chukchi seas

Norwegian Sea

Peel Sound

Pond Inlet, Eclipse Sound, Admiralty Inlet

Prince Regent Inlet

Predators

Cephalopod prey

narwhal (Monodon monoceros) ${ }^{a}$

thick-billed murre chicks (Uria lomvia) ${ }^{b}$

beluga whale (Delphinapterus leucas) ${ }^{c}$

narwhal (Monodon monoceros) ${ }^{d}$

harp seal (Phoca groenlandica) ${ }^{c}$

hooded seal (Cystophora cristata) ${ }^{c}$

bearded seals (Erignathus barbatus) ${ }^{\mathrm{e}}$

ribbon seal pups (Histriophoca fasciata) ${ }^{\mathrm{e}}$

spotted seals (Phoca largha) ${ }^{\mathrm{e}}$

walrus (Odobenus rosmarus) ${ }^{\mathrm{e}}$

narwhal (Monodon monoceros) ${ }^{a}$

bearded seals (Erignathus barbatus) ${ }^{\mathrm{e}}$

thick-billed murre chicks (Uria lomvia) ${ }^{b}$

thick-billed murre chicks (Uria lomvia) ${ }^{b}$

harp seal (Phoca groenlandica) ${ }^{\dagger}$

hooded seal (Cystophora cristata) ${ }^{\dagger}$

beluga whale (Delphinapterus leucas) ${ }^{d}$

Greenland halibut (Reinhardtius hippoglossoides) ${ }^{d}$

harp seal (Phoca groenlandica) ${ }^{d}$

hooded seal (Cystophora cristata) ${ }^{\text {d }}$

sperm whale (Physeter macrocephalus) ${ }^{d}$

narwhal (Monodon monoceros) ${ }^{a}$

beluga whale (Delphinapterus leucas) ${ }^{g}$

thick-billed murre chicks (Uria lomvia) ${ }^{b}$

northern bottlenose whale (Hyperoodon ampullatus) ${ }^{h}$

long-finned pilot whale (Globicephala melas)'

sperm whale (Physeter macrocephalus)

cod (Gadus sp.) $)^{\text {h }}$

Halibut sp. ${ }^{\text {h }}$

northern bottlenose whale (Hyperoodon ampullatus) ${ }^{j}$ narwhal (Monodon monoceros) ${ }^{a}$

narwhal (Monodon monoceros) ${ }^{a}$

beluga whale (Delphinapterus leucas) ${ }^{\mathrm{g}}$

beluga whale (Delphinapterus leucas)

blue ling (Molva dypterygia)

cod (Gadus sp.) $)^{\mathrm{j}}$

Greenland halibut (Reinhardtius hippoglossoides)'

Greenland shark (Somniosus microcephalus)'

grenadier fish sp.!

harp seal (Phoca groenlandica) $)^{\mathrm{j} k}$

hooded seal (Cystophora cristata $)^{\mathrm{j}, \mathrm{k}}$

narwhal (Monodon monoceros) $)^{\mathrm{j}}$

northern bottlenose whale (Hyperoodon ampullatus)

long-finned pilot whale (Globicephala melas) ${ }^{i}$

saithe (Pollachius virens) ${ }^{j}$

sea perch sp.

seabirds'

Sowerby's beaked whale (Mesoplodon bidens)'

sperm whale (Physeter macrocephalus)

narwhal (Monodon monoceros) $)^{a}$

narwhal (Monodon monoceros)'

narwhal (Monodon monoceros) ${ }^{\mathrm{a}}$ squid

Gonatus fabricii

cephalopods

squid

squid

Gonatus sp.

Octopus sp.

cephalopods

cephalopods

Octopus sp.

Squid

Octopus sp.

Gonatus fabricii

Gonatus fabricii

Gonatus fabricii

Gonatus fabricii

cephalopods

squid

squid

squid

squid

squid

cephalopods

Gonatus fabricii

Gonatus sp.

Gonatus sp.

Gonatus sp.

Gonatus sp.

Ommastrephidae

Gonatus sp.

Ommastrephidae

Gonatus sp.

squid

squid

Gonatus sp.

Octopus sp.

Gonatus sp.

Gonatus sp.

Gonatus sp.

Gonatus sp.

Gonatus sp.

Gonatus sp.

Gonatus sp.

squid

Gonatus sp.

Gonatus sp.

Gonatus sp.

Gonatus sp.

Gonatus sp.

Gonatus sp.

Gonatus sp.

Gonatus sp.

Gonatus sp.

Gonatus sp.

squid

squid

squid 
Table 4 Continued

\begin{tabular}{|c|c|c|}
\hline Location & Predators & Cephalopod prey \\
\hline southern Greenland & Greenland halibut (Reinhardtius hippoglossoides) ${ }^{\mathrm{m}}$ & squid \\
\hline Tremblay Sound, Creswell Bay & narwhal (Monodon monoceros)i & Gonatus sp. \\
\hline \multirow[t]{2}{*}{ western Alaska } & beluga whale (Delphinapterus leucas) ${ }^{g}$ & Gonatus sp. \\
\hline & & Octopus sp. \\
\hline \multirow[t]{4}{*}{ Within the predators' natural range } & harbour seal (Phoca vitulina) ${ }^{\mathrm{d}, \mathrm{o}}$ & squid \\
\hline & ribbon seal (Histriophoca fasciata) $)^{d, o}$ & squid \\
\hline & spotted seal (Phoca largha) $)^{\mathrm{d}, o}$ & squid \\
\hline & narwhal (Monodon monoceros) $)^{d, o}$ & Gonatus fabricii \\
\hline
\end{tabular}

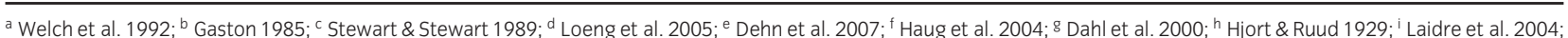
${ }^{j}$ Bjørke 2001; ${ }^{\text {k }}$ Dommasnes et al. 2001; ' Hay \& Mansfield 1989; ${ }^{m}$ Woll \& Gundersen 2004; ${ }^{n}$ COSEWIC 2004; ${ }^{\circ}$ Tomilin 1967 (1957).

and Lady Ann Strait, and along the west coast of Greenland (Fig. 7). Records exist from the middle of the east coast of Greenland through Denmark Strait to Iceland, and down to the Faroe Islands (Fig. 7). Bathypolypus arcticus is also found offshore of Norway and in the Norwegian Sea to Svalbard (Fig. 7). There are also reports from the Kara and Laptev seas (Fig. 7). The most western distribution is from the Canada Basin, north of Alaska (Fig. 7). Areas of interest are Kap Powlett, Greenland and the Laptev Sea (Fig. 7).

Specimens are typically recovered from trawls. One was found in the stomach of a narwhal caught at Pond Inlet (Fig. 8). The specimen from Lichtenaufjord, Greenland, was from the stomach contents of a Greenland halibut (Fig. 8).

\section{Cirroteuthis muelleri distribution}

The majority of C. muelleri specimens are from Baffin Bay, and the Norwegian and Greenland seas, with a few records from the Laptev Sea (Fig. 9). C. muelleri is also reported from the deep water of the Canada Basin (Raskoff et al. in press; B. Bluhm, pers. comm. 2007), and from Davis Strait and Baffin Bay (Fig. 9).

\section{Unidentified cephalopods}

Although not much cephalopod research has been conducted in the Canadian Arctic, there are records of unidentified cephalopods (typically from fishery or bird surveys) from areas such as Pond Inlet, Arctic Bay, Cape Vera, Somerset Island and Peel Sound, NU, with other records from Liverpool Bay, southern Banks and Victoria islands, NWT (Fig. 10).

\section{Rare species of the Canadian Arctic Ocean and adjacent areas}

Deep-sea squid like the giant squid (Architeuthis sp. Steenstrup) and temperate species such as Illex illecebrosus
Lesueur and Sepiola atlantica D'Orbigny have been reported from Greenland (e.g., Berry 1925; Grimpe 1933; Nesis 1987; Table 1). Architeuthis sp. have also been reported from Iceland and the Norwegian coastline, wheras Loligo forbesi Steenstrup has been reported from the Norwegian Sea (Table 1). Rossia glaucopis Loven is reported along the eastern shore of Greenland, and its presence was noted in Svalbard, the Faroe Islands, and the Barents and Kara seas (Table 1). Bathypolypus bairdii Verrill and Muus's (2002) proposed species Bathypolypus pugniger were found through the Denmark Strait and around Greenland, with B. bairdii extending west into the Davis Strait (Table 1). Both were reported (Treble 2007) from Baffin Bay in the 2006 NAFO fishery survey (Table 1). Numerous Gonatus sp., Bathypolypus sp. and Rossia sp. were also collected throughout the Hudson Strait (Table 1).

\section{Cephalopod-predator interactions}

The percentage of diets comprising cephalopods of various Arctic species is listed in Table 2. Cephalopods comprised ca. $90 \%$ of the diet of Bering Sea beaked (Mesoplodon stejnegeri True) and Baird's beaked (Berardius bairdii Stejneger) whales (Table 2). The diet of sperm whales is ca. $72-96 \%$ cephalopods (Table 2). Santos et al. (2001) reported that $96 \%$ (by weight) of prey items in stranded sperm whale stomachs from Norwegian waters were Gonatus sp. Other mammalian predators from the Bering Sea, such as northern fur seals (Callorhinus ursinus L.) and Dall's porpoise (Phocoenoides dalli True), have $33-50 \%$ of their diets made up of squid (Table 2 ). Thickbilled and common murres (Uria spp.) off Bjørnøya and Bleiksøy, Norway, have $30 \%$ and $40 \%$ of their diets represented by squid and G. fabricii (Table 2 ).

The percentage occurrence of indigestible cephalopod parts (mostly beaks) and flesh from the stomachs of sampled predators is listed in Table 3. These records indicate cephalopod remains, but not the relative proportion 


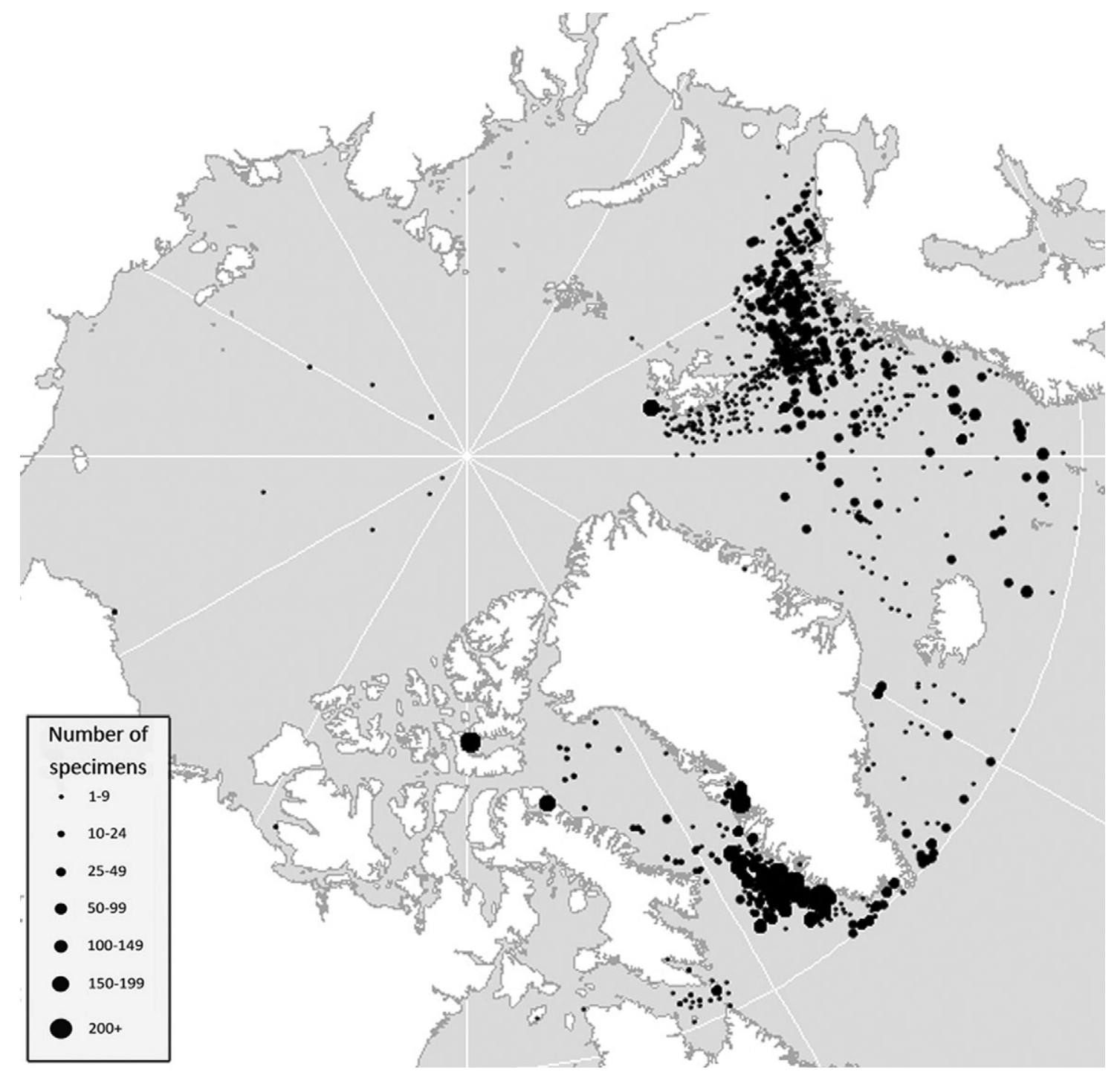

Fig. 1 Circumpolar records of Gonatus fabricii. Sources: Berry (1925); Hjort \& Ruud (1929); Grieg (1930) and Kubodera \& Tsuchiya (1993), as cited in Cephbase; Grimpe (1933); Muus (1962); Nesis (1965, 2001, 2003 [1971]); Young (1973); Kristensen (1977, 1982); Finley \& Gibb (1982); Wiborg et al. (1982); Gaston (1985); Sennikov et al. (1989); Piatkowski \& Wieland (1993); Barrett et al. (1997); B. Bluhm (pers. comm. 2007); Zumholz et al. (2007); Atlantic Reference Centre collection; Canadian Museum of Nature collection; Atlantic Reference Centre online database; Smithsonian National Museum of Natural History online database; Northwest Atlantic Fisheries Organization (NAFO) fishery survey of 2004 (M. Treble, pers. comm.); NAFO survey of 2007 (M. Treble, pers. comm.); Raskoff et al. in press; and T.A. Dick (unpubl. data). Forty-two specimens were collected during the NAFO trawl surveys in 2006 . They were caught along the west side of Baffin Bay between depths of 425.5 and $1482.5 \mathrm{~m}$ (Treble 2007).

in the diets. All bottlenose whales (Hyperoodon ampullatus Forster) sampled around Iceland had squid remains in their stomachs, and $92 \%$ of narwhals caught off Pond Inlet in 1978 had G. fabricii parts in their digestive tracts $(79 \%$ in 1979) (Table 2). Cephalopods comprised $67-71 \%$ of the diet of bearded seals (Erignathus barbatus Erxleben) from Grise Fjord (Table 2), and $69.4 \%$ of the diet was unidentified octopods near Barrow, Alaska (Table 3). Of the sperm whales collected off Andenes, Norway, in 1971, 83\% had squid beaks in their stomachs (Table 3).
More than $50 \%$ of the anecdotal accounts of diets of Arctic predators list Gonatus sp. (likely to be G. fabricii based on locations) in the diets, indicating its importance as a prey species (Table 4 ).

\section{Discussion}

Recent studies have shown that cephalopods, specifically the high-energy keystone species G. fabricii, are important prey for a variety of Arctic predators (Frandsen \& Wieland 2004; Chambers \& Dick 2007). With increasing water 


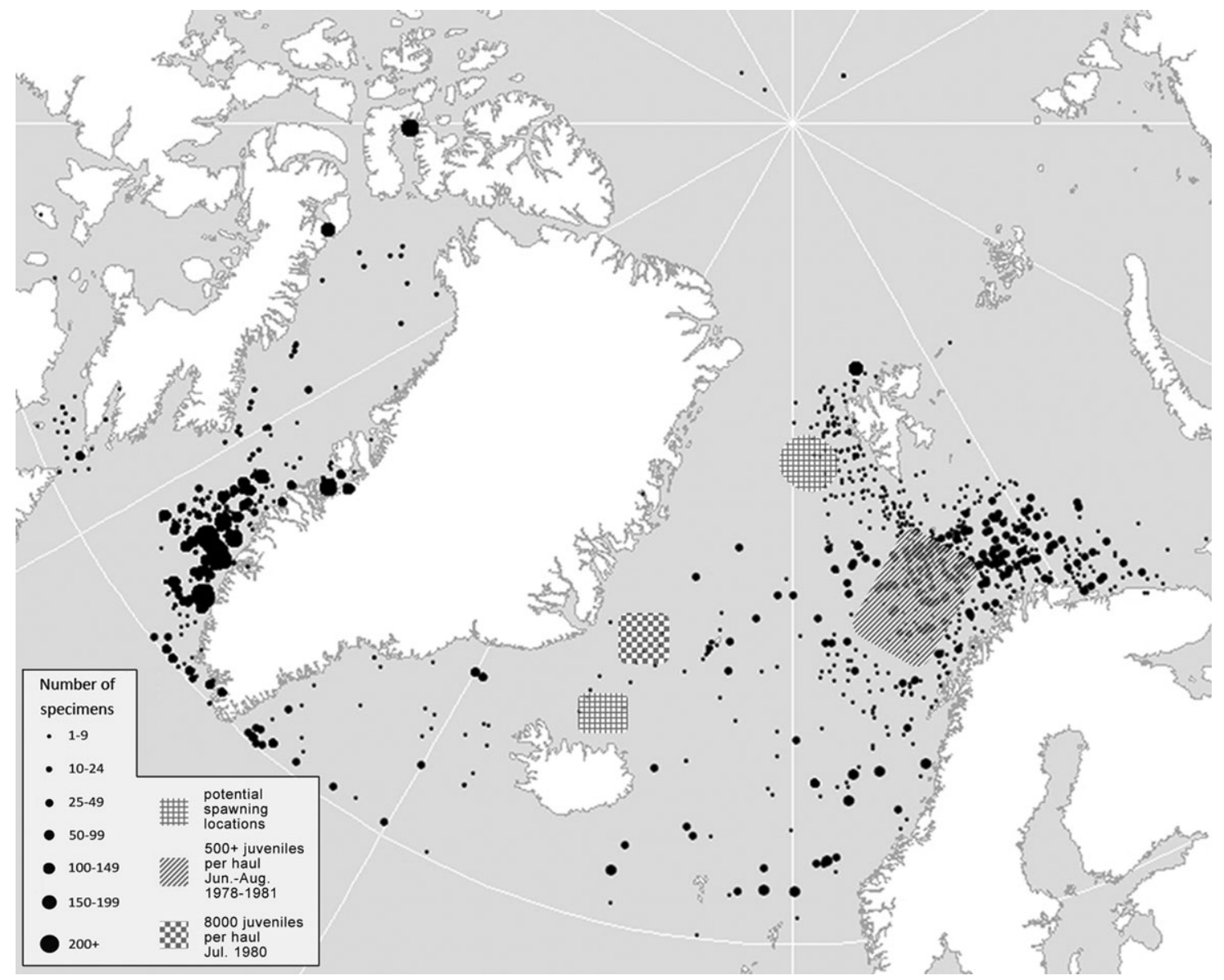

Fig. 2 Distribution of Gonatus fabricii in the western European Arctic with reference to potential spawning locations, areas of 500+ juveniles per haul caught between June and August 1978-1981 and a region where 8000 juveniles per haul were recorded in July 1980 (Wiborg et al. 1982). For a more accurate representation of the juvenile distribution of G. fabricii, see Wiborg et al. (1982: fig. 1).

temperatures, more temperate species, such as I. illecebrosus and L. forbesi, are likely to become more common, thereby increasing the competition for prey and adding to the predation pressure on such species as G. fabricii (O'Dor 1983). It is unknown what impact these potential shifts in predator-prey interactions might have on the overall food web.

\section{Arctic cephalopod range extensions}

Gonatus fabricii. We extend the range of G. fabricii from that described by Clarke (1966). This new distribution includes the eastern Siberia Sea, the Beaufort Sea (Canada Basin) (Raskoff et al. in press; B. Bluhm, pers. comm. 2007), Pond Inlet (stomach contents of narwhals) and the most northern Canadian Arctic location, Cape Vera (T.A. Dick, unpubl. data; Fig. 1). Although not reported by Nesis (2001), specimens from the Dolphin and Union Strait (ARC; Fig. 1) give validity to Nesis's description of a circumpolar species.
Discrepancies have been noted between the range described in this study and previously reported distributions, especially from the Pacific Ocean. Other regions of the Pacific Ocean probably represent a different species of gonatid (Wiborg et al. 1982).

Rossia moelleri. Nesis (2001) noted that R. moelleri is not typically found south of $75^{\circ} \mathrm{N}$, although a "questionable" specimen from Franklin Bay was reported. The present range includes specimens collected south of $75^{\circ} \mathrm{N}$ near Cape Parry and Coronation Gulf, and extending into waters around Iceland (Fig. 4). The range also extends to the interior of Frobisher Bay and Melville Island (Fig. 4).

Rossia palpebrosa. With a distribution throughout most of the Arctic Ocean (Nesis, 2001), R. palpebrosa has a similar range to $R$. moelleri. The present distribution reflects that described by Nesis (2001), with the exception of no records from Iceland or the Danish Strait 


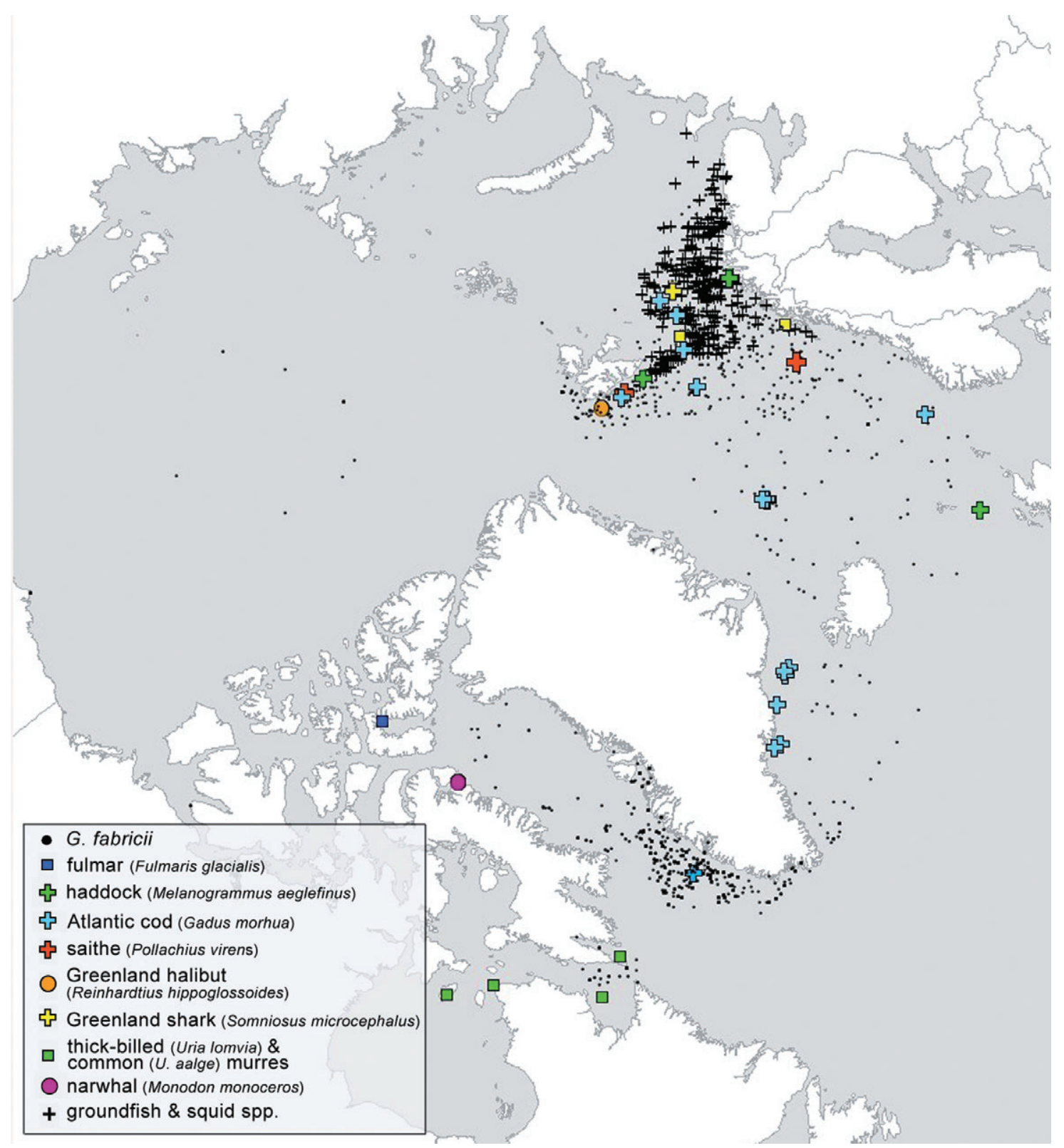

Fig. 3 Occurrence records of Gonatus fabricii specimens, including remains in the stomach contents of predators. Sources: Berry (1925); Hjort \& Ruud (1929); Grieg (1930) and Kubodera \& Tsuchiya (1993), as cited in Cephbase; Grimpe (1933); Muus (1962); Nesis (1965, 2001, 2003 [1971]); Young (1973); Kristensen (1977, 1982); Wiborg et al. (1982); Finley \& Gibb 1982; Gaston 1985; Sennikov et al. (1989); Piatkowski \& Wieland (1993); Barrett et al. (1997); B. Bluhm (pers. comm. 2007); Zumholz et al. (2007); Atlantic Reference Centre collection; Canadian Museum of Nature collection; Atlantic Reference Centre online database; Smithsonian National Museum of Natural History online database; Northwest Atlantic Fisheries Organization (NAFO) (M. Treble pers. comm.); NAFO survey of 2007 (M. Treble, pers. comm.); Raskoff et al. in press; and T.A. Dick (unpubl. data).

(Fig. 6). The range is extended in the Canadian Arctic to Hudson Strait, the mouth of Cumberland Sound, Frobisher Bay, and Somerset and Ellesmere islands (Fig. 6).

Bathypolypus arcticus. Muus's (2002) re-description of the $B$. arcticus complex requires most museum specimens to be re-examined and identified under the new criteria. Based on current museum records, our map shows a distribution south from Hudson Strait to Frobisher Bay, southern Davis Strait and north to Lady Ann Strait (Fig. 7). The species identification of samples collected around the United Kingdom, Norway and southern Greenland are questionable, as they occur in areas of 


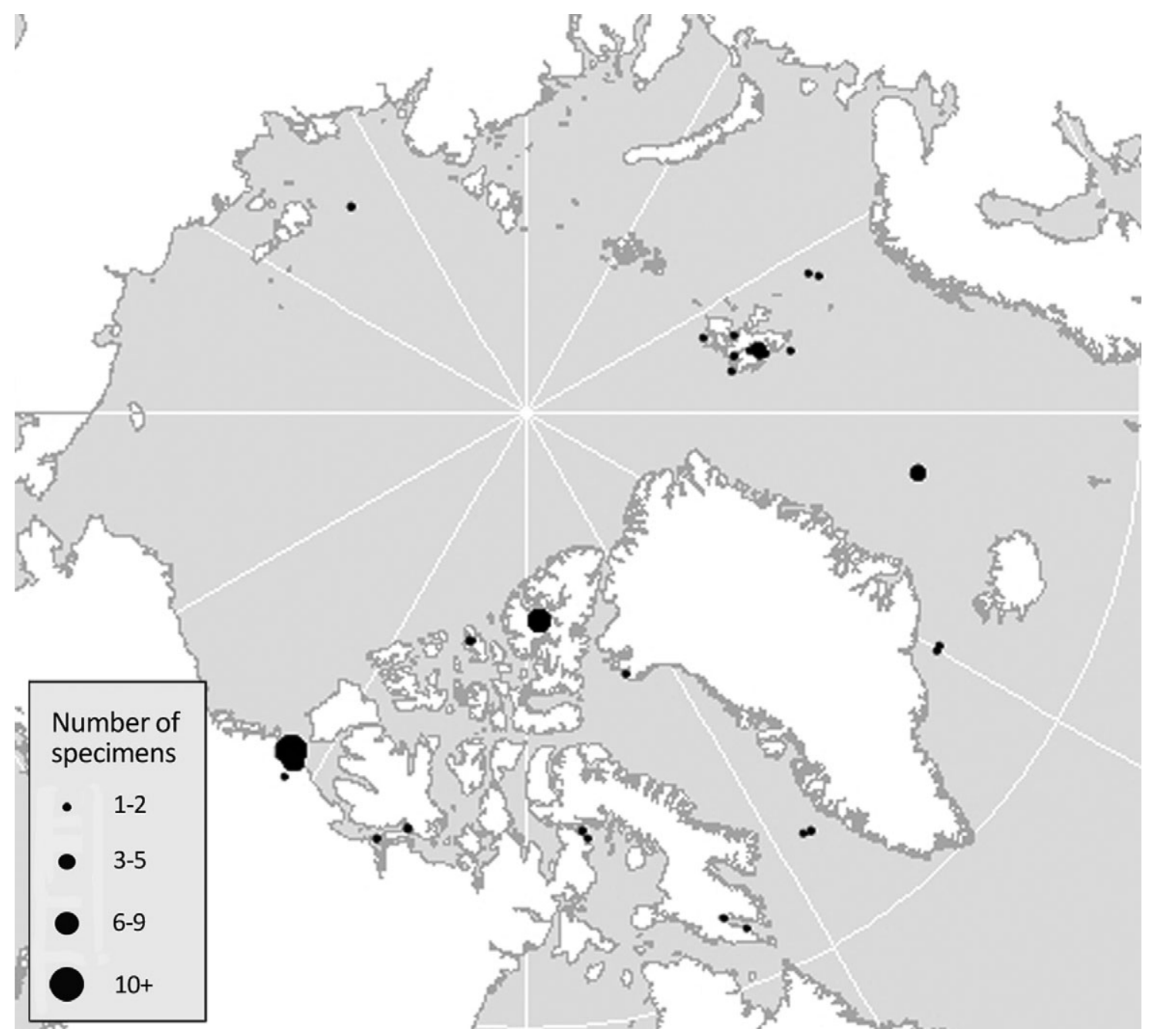

Fig. 4 Circumpolar records of Rossia moelleri. Sources: Grieg (1930), as cited in Cephbase; Grimpe (1933); Kondakov (1937); Muus (1962); Wacasey et al. (1979); Atkinson \& Wacasey (1989); Nesis (2001); Canadian Museum of Nature collection; and Atlantic Reference Centre online database. One specimen of $R$. moelleri was caught between a depth of 139 and $150.5 \mathrm{~m}$ from the western side of Baffin Bay during Northwest Atlantic Fisheries Organization trawl surveys in 2006 (Treble 2007).

potential overlap between B. arcticus, B. bairdii and $B$. pugniger sp. (Fig. 7) (Muus 2002).

A specimen from Cape Parry (CMNML) (Fig. 7) was confirmed as the westernmost Canadian distribution of $B$. arcticus; however, records extend the range further west to Point Barrow, Alaska, and the Canada Basin (Fig. 7). These locations extend the range west from Muus's (2002) original description. Only two specimens were recorded by Muus (2002) from Canadian waters, one from Devon Island and the other just off the Cumberland Peninsula, Baffin Island. The current map extends the species to Pond Inlet and Frobisher Bay. Our distribution re-affirms O'Dor \& Macalaster's (1983) and Nesis's (2001) claim of a western Canadian distribution.
Cirroteuthis muelleri. Nesis (2001) described C. muelleri as a circumpolar species found in deep water (500$3786 \mathrm{~m})$, and our range agrees, with the exception of specimens from the shallower Laptev Sea (Fig. 9). Additional locations were identified from the Canada Basin, based on plankton samples and remotely operated vehicle surveys by ArcOD and the NOAA Ocean Explorer (Raskoff et al. in press; B. Bluhm, pers. comm. 2007; Fig. 9). The greatest number of samples caught in one location $(n=63)$ were caught in northern Baffin Bay (Fig. 9).

Additional Arctic cephalopod distributions. Several other species have been reported from the Arctic (Table 1), and of these B. bairdii and R. glaucopis were the 


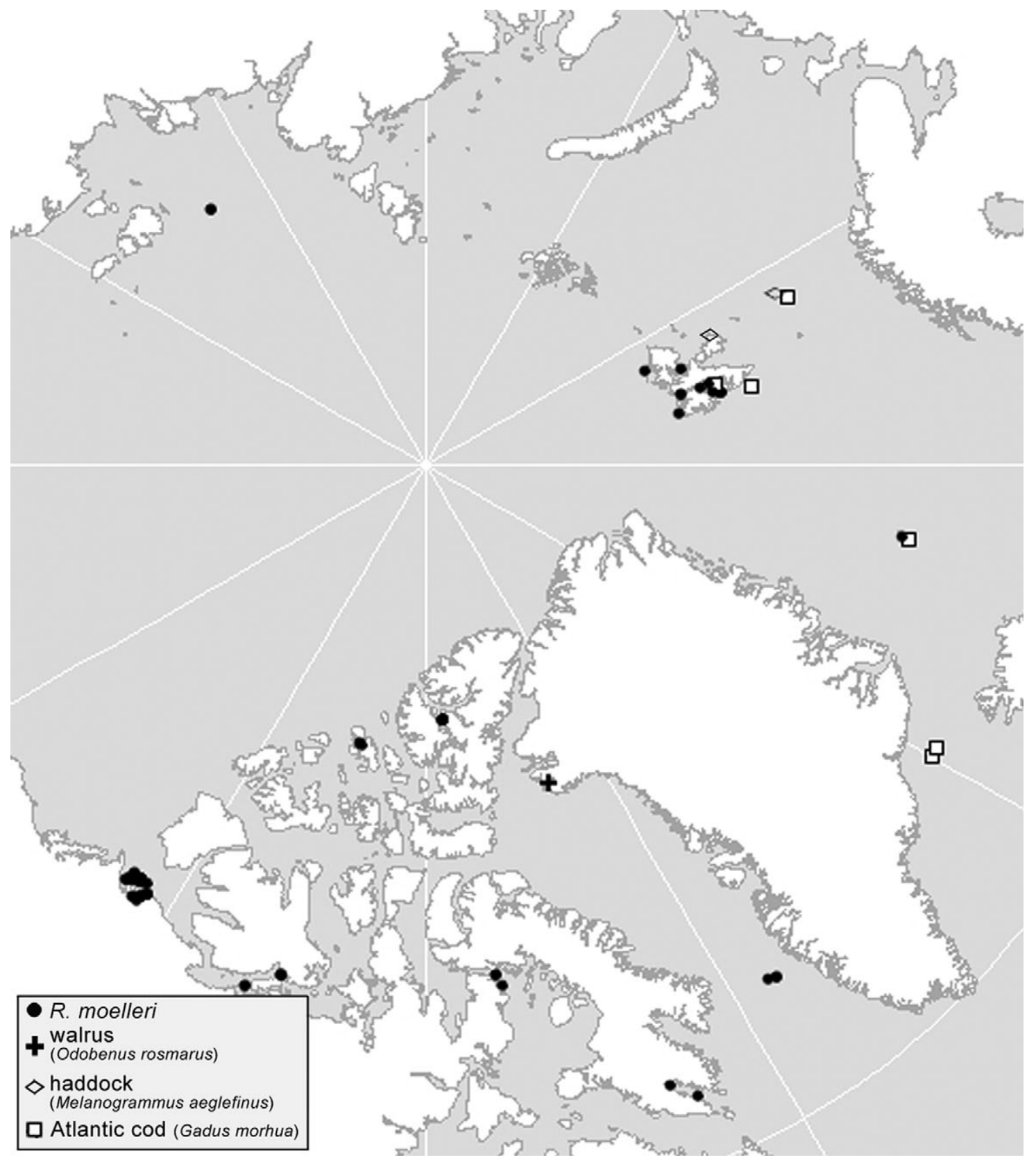

Fig. 5 Circumpolar records of Rossia moelleri specimens, including remains in the stomach contents of predators. Sources: Grieg (1930), as cited in Cephbase; Grimpe (1933); Kondakov (1937); Muus (1962); Wacasey et al. (1979); Atkinson \& Wacasey (1989); Nesis (2001); Canadian Museum of Nature collection; and Atlantic Reference Centre online database.

most abundant (Table 1). The remaining species are listed in Table 1.

\section{Predator-prey relationships}

Arctic predators of cephalopods are often large and mobile. Consequently, the source of samples collected needs to be considered when designating an "area of interest". Areas with large numbers of recorded specimens may indicate a greater abundance of cephalopods or may be associated with an active sampling programme of a nearby field station or traditional hunting grounds. The latter may also indirectly reflect an abundance of prey in that particular region. 


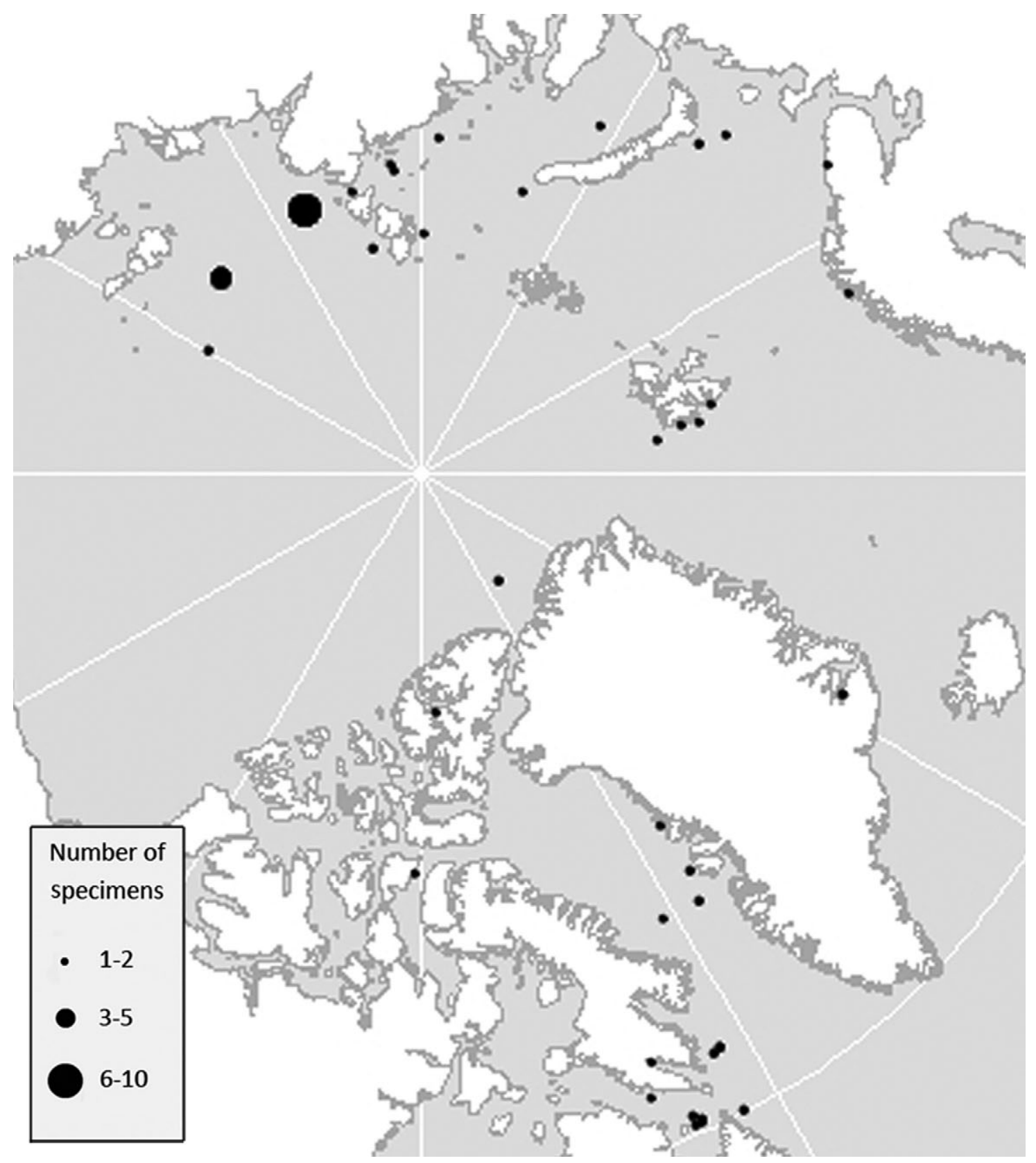

Fig. 6 Circumpolar records of Rossia palpebrosa. Sources: Grimpe (1933); Kondakov (1937); Wacasey et al. (1979); Nesis (2001); Canadian Museum of Nature collection; and Atlantic Reference Centre online database. Seven specimens were collected from the western side of Baffin Bay during Northwest Atlantic Fisheries Organization trawl surveys in 2006. They were all caught between depths of 123 and $611.5 \mathrm{~m}$ (Treble 2007).

Cape Vera and Pond Inlet are areas where northern fulmars are studied and narwhals are traditionally hunted. Records from both locations indicate that more than 100 samples of G. fabricii were collected from individual fulmar and narwhal stomachs (Figs. 1, 3). This distribution may indicate areas of greater cephalopod concentrations where predators congregate to feed. However, cephalopod beaks can accumulate in stomachs over time, with unknown expulsion rates (Lowry et al. 1986), which could result in an overestimation of predation pressure (Santos et al. 2001). Arctic predators are also migratory, and beaks collected from a sample from one location may be acquired from a different region. In the case of Cape Vera, the northern fulmars were believed to not travel great distances to forage, but a recent survey of the area found only a few individuals hunting in the 


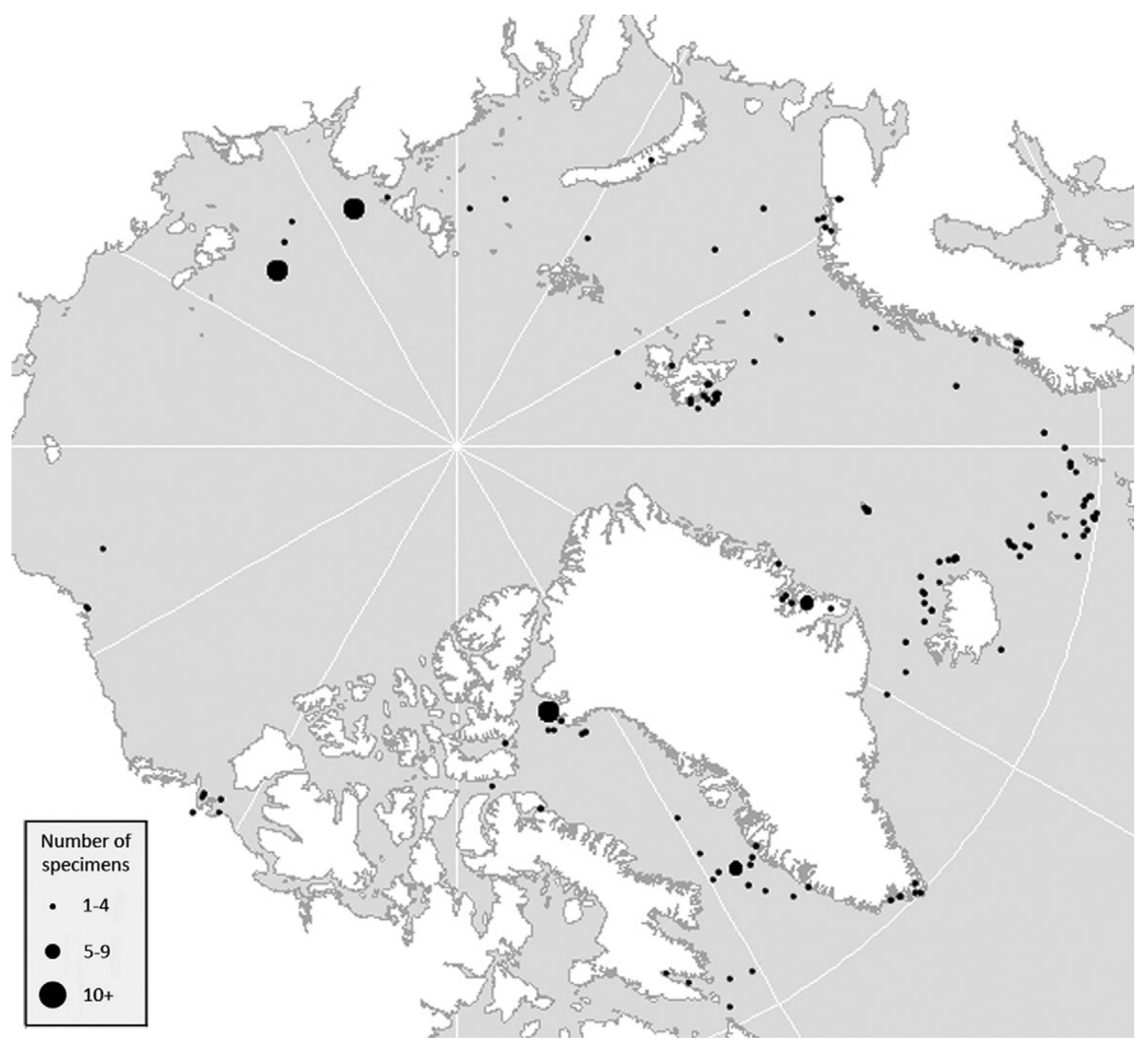

Fig. 7 Circumpolar records of Bathypolypus arcticus. Not included is a record (Taxonomic Information System for the Belgian Coastal Area online database) from the centre of Iceland. Sources: Hoyle (1886), Grieg (1930), Robson (1931), Adam (1939) and Macalaster (1976), as cited in Cephbase; Grimpe (1933); Kondakov (1937); Muus (1962, 2002); Wacasey et al. (1979); Finley \& Gibb (1982); Atkinson \& Wacasey (1989); Stewart et al. (1993); Nesis (2001); Canadian Museum of Nature collection; Smithsonian National Museum of Natural History online database; Northwest Atlantic Fisheries Organization (NAFO) survey of 2004 (M. Treble, pers. comm.); and NAFO survey of 2007 (M. Treble, pers. comm.).

nearby Hell Gate polynya, suggesting foraging trips of greater distances (Mallory \& Gilchrist 2005). However, as Cape Vera is a breeding colony, it is unlikely that the birds would venture too far in search of food while caring for their young. Also, beaks may indirectly enter a predator's stomach when the animal feeds on a teuthophagus predator (Santos et al. 2001).

Increased sample numbers from a region may also reflect an active commercial fishery with a substantial bycatch. Large numbers of $G$. fabricii are reported from trawls along the south-west coast of Greenland (Fig. 1), and are frequently recovered as bycatch in the shrimp fishery (Kristensen 1983; Piatkowski \& Wieland 1993;
Zumholz \& Frandsen 2006). Similarly, B. arcticus distribution is frequently reported from trawls (Stewart et al. 1993) (Figs. 7, 8).

\section{Oceanographic variables and distributions}

Many species of cephalopod have planktonic life stages, and ocean currents influence dispersal and local retention. Reports from the Norwegian Sea (between Jan Mayen and Vesterålen) indicate high densities of cephalopods, particularly G. fabricii, in areas with eddies (Figs. 2, 3; Wiborg et al. 1982). Larval G. fabricii cannot contract mantle muscles to drive active locomotion (e.g., 


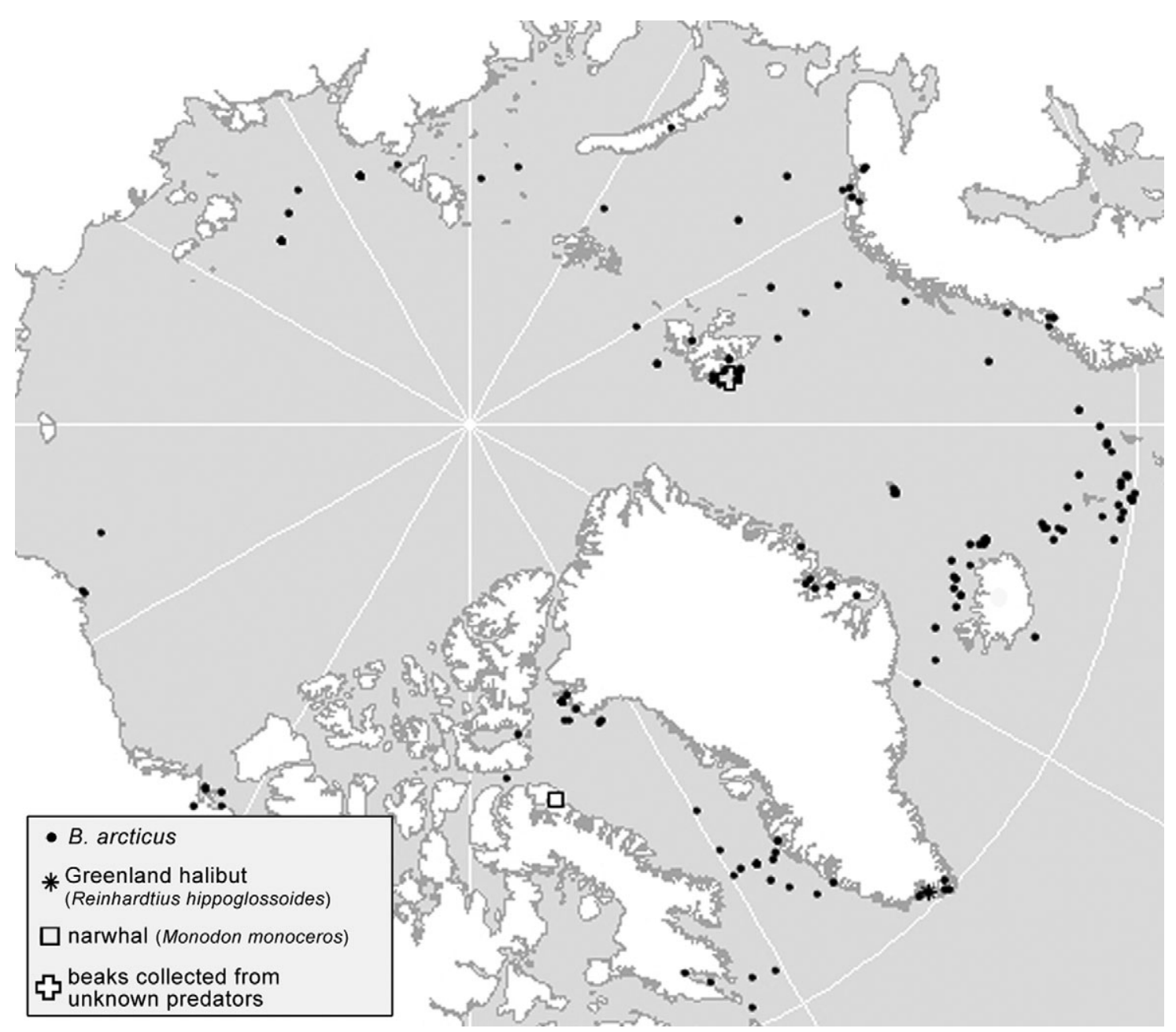

Fig. 8 Circumpolar records of Bathypolypus arcticus specimens, including remains in the stomach contents of predators. Sources: Hoyle (1886), Grieg (1930), Robson (1931), Adam (1939) and Macalaster (1976), as cited in Cephbase; Grimpe (1933); Kondakov (1937); Muus (1962, 2002); Wacasey et al. (1979); Finley \& Gibb (1982); Atkinson \& Wacasey (1989); Stewart et al. (1993); Nesis (2001); Canadian Museum of Nature collection; Smithsonian National Museum of Natural History online database; Northwest Atlantic Fisheries Organization (NAFO) survey of 2004 (M. Treble, pers. comm.); and NAFO survey of 2007 (M. Treble, pers. comm.).

Nesis, 1965; Kristensen, 1983; Arkhipkin \& Bjørke 1999), and, similarly, mature females lose musculature and revert back to a planktonic way of life (e.g., Clarke 1966; Kristensen 1983; Arkhipkin \& Bjørke 1999). By contrast, $B$. arcticus and Rossia species lack a planktonic stage, and are not greatly influenced by currents (Sweeney et al. 1992; Wood 2000).

Depth is another key variable, as $C$. muelleri is typically limited to deep water regions in the Arctic Ocean and Baffin Bay (Fig. 9).

Polynyas, regions with wind-induced upwellings and direct access to sunlight, have increased productivity (Brown \& Nettleship, 1981). The Canadian Arctic has several polynyas, including the large North Water in Baffin Bay (Michel et al. 2006). The distributions of some cephalopod species may correlate with these open water areas. An example is cephalopods from Cape Parry, a potential "hotspot" affected by the Cape Bathurst flaw lead (Michel et al. 2006). This lead creates higher productivity and, in turn, provides greater quantities of prey for cephalopods. Large numbers of $B$. arcticus were also collected off Greenland near the North Water Polynya. Nesis (2003 [1971]) suggested that cephalopods caught in the High Arctic through holes in the ice from drifting stations may have been responding to increased light. If this is the case, polynyas are likely to be the areas with most light during the winter months in the Arctic Ocean, and may explain, at least in part, the occurrences of greater numbers of cephalopods and their predators. 


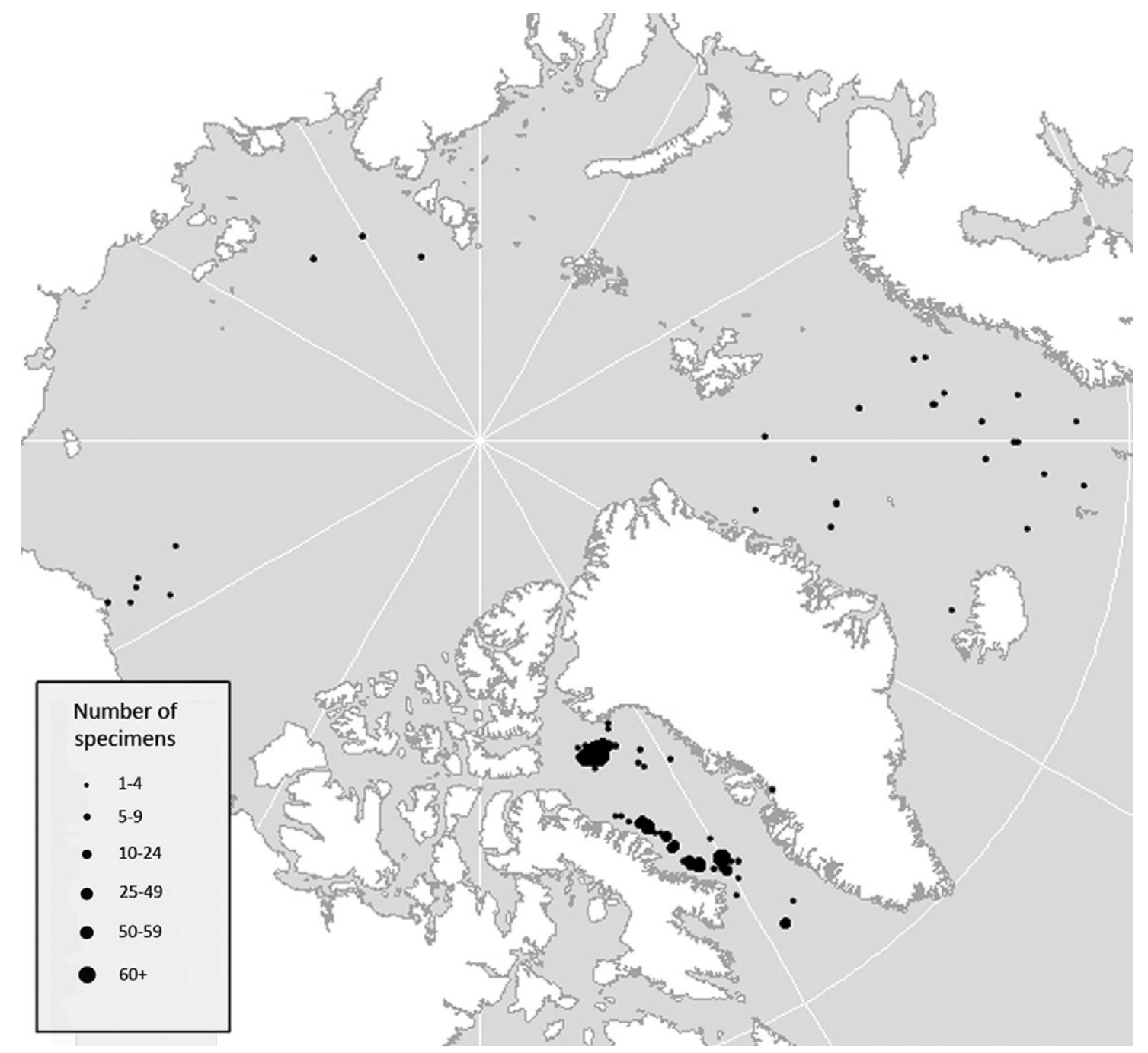

Fig. 9 Circumpolar records of Cirroteuthis muelleri. Forty-five individuals were collected from the western side of Baffin Bay during Northwest Atlantic Fisheries Organization (NAFO) trawl surveys in 2006. They were collected between the depths of 103 and $1482.5 \mathrm{~m}$ (Treble 2007). Sources: Grieg (1930) and Robson (1931), as cited in Cephbase; Grimpe (1933); Muus (1962); Nesis (1987, 2001); Collins (2002); B. Bluhm (pers. comm. 2007); Raskoff et al. in press; Ifremer BIOCEAN database 2007; Smithsonian National Museum of Natural History online database; Swedish Museum of Natural History online database; and NAFO survey of 2004 (M. Treble, pers. comm.).

\section{Predator-prey distributions relative to ocean variables}

Predators are often reported in areas with an abundance of cephalopods (Hjort \& Ruud, 1929). Table 4 lists predators found in the Norwegian Sea near retention areas with strong circular currents (Wiborg et al. 1982; Dommasnes et al. 2001), where planktonic cephalopods (e.g., larvae) are likely to become concentrated. Narwhals feeding near Pond Inlet may be responding to greater prey abundance caused by currents in Baffin Bay and the local polynya (WHOI 2006; Barber \& Massom 2007). Belugas have also been reported from the Amundsen Gulf (L. Harwood, pers. comm. 2007), which is an area of cephalopod aggregations (Figs. 1-10), possibly as a result of eddies formed by the influx of water from the Bering Sea (WHOI 2006) or by the retention from the Cape Bathurst polynya flaw lead (Barber \& Massom 2007).

\section{Summary}

In summary, cephalopods play an important role in Arctic food webs, and are highly dependent on oceanographic processes for distribution. Further research on the collection of quantitative trawl data in biologically sensitive areas, in areas of active ocean currents and remote regions of the Canadian Arctic are urgently needed. Furthermore, a comprehensive compilation of community- 


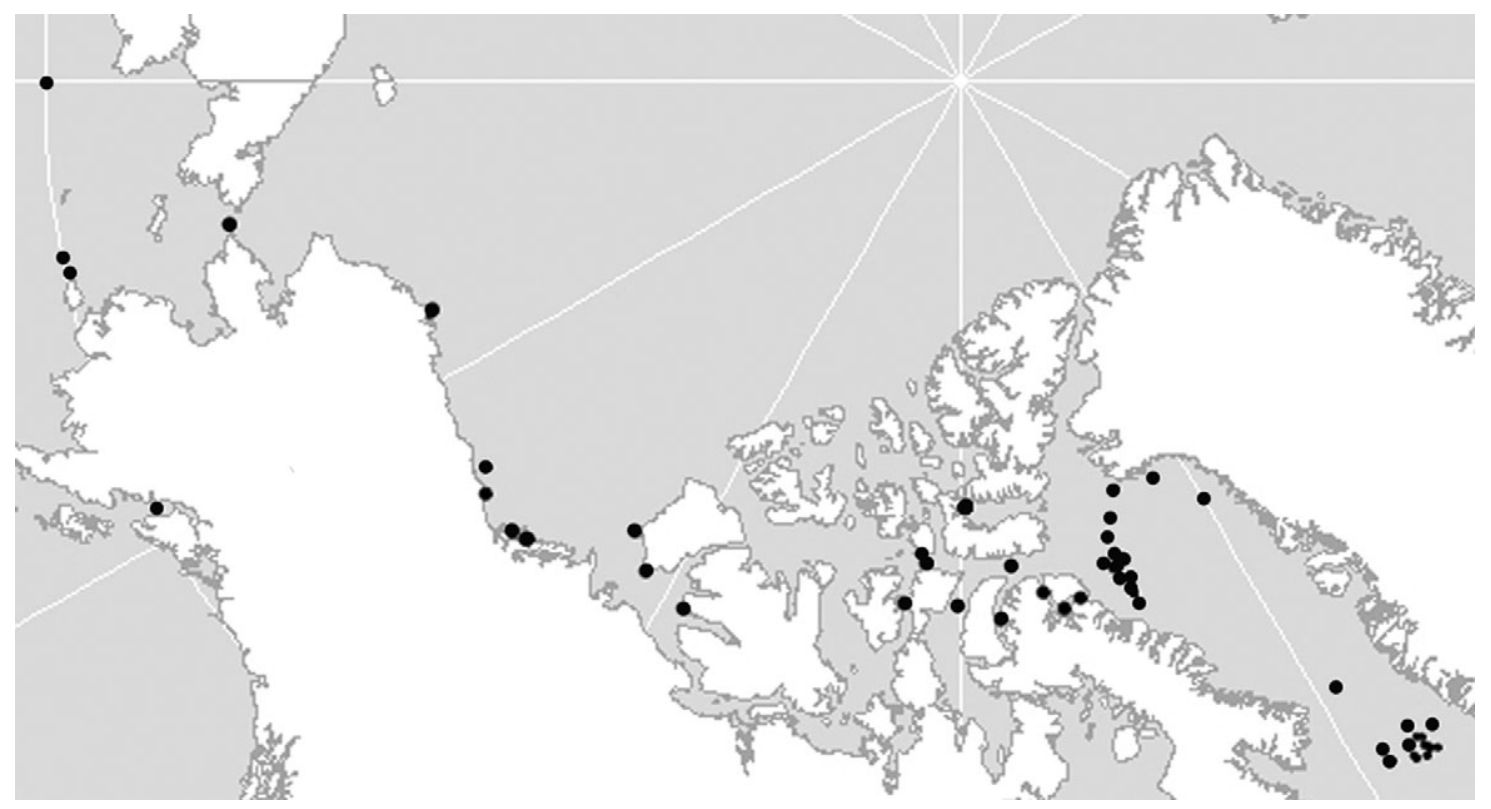

Fig. 10 Canadian records of unidentified cephalopods. Not included are a record of an unidentified cephalopod from central Norway and one from Alaska (coordinates not accurate). Sources: Hay \& Mansfield (1989); Welch et al. (1992); Stewart et al. (1993); Dehn et al. (2007); L. Harwood (pers. comm. 2007); Smithsonian National Museum of Natural History online database; Northwest Atlantic Fisheries Organization (NAFO) survey of 2004 (M. Treble, pers. comm.); NAFO survey of 2007 (M. Treble, pers. comm.); and T.A. Dick (unpubl. data).

based data on the diets of the commonly harvested marine predators will substantially increase the knowledge of this important group of invertebrates. Equally important is information on the physiological requirements of Arctic animals and climate change. Portner and Farrel (2008) discuss poleward shifts in the geographical distributions of animals, population collapses, changes in seasonal timing of biological events and changes in food-web structure, all of which are influenced by environmental temperatures. Cephalopods inhabit both deep and shallow waters, and some of their larvae are dispersed by surface waters, which make them vulnerable to temperature changes at all depths. Data are needed on cephalopod optimum temperature ranges and oxygen requirements. These baseline data are essential to clarify the importance and distribution of this nutrient-rich food source in Arctic marine food webs in the context of ice loss, warming waters, altered ocean currents, salinity and alien species invasions, including the large cephalopod predators.

\section{Acknowledgements}

TAD acknowledges financial support from a Natural Sciences and Engineering Research Council of Canada Northern Research Chair, and KG thanks the Faculty of Science, University of Manitoba, for partial financial support through a Graduate Scholarship. We thank Dr.
M. Papst and M. Treble, Department of Fisheries and Oceans, Winnipeg, for support and access to trawl data from surveys in the Davis Strait and Baffin Bay area. We also thank the reviewers for their helpful and constructive comments, which significantly improved the manuscript. Additional thanks go to Drs. Gretta Pecl, Clyde Roper and Michael Vecchione for help in obtaining Nesis's translated works. We thank Dr. Nigmatullin for suggesting some important manuscripts.

\section{References}

Academy of Natural Sciences Malacology Database. Online database accessed through Global Biodiversity Information Facility (GBIF) Data Portal at http://data.gbif.org/datasets/ resource/175 on 5 November 2007.

Arkhipkin A.I. \& Bjørke H. 1999. Ontogenetic changes in morphometric and reproductive indices of the squid Gonatus fabricii (Oegopsida, Gonatidae) in the Norwegian Sea. Polar Biology 22, 357-365.

Atlantic Reference Centre. Online database accessed through Global Biodiversity Information Facility (GBIF) Data Portal at http://data.gbif.org/datasets/resource/341 on 5 November 2007.

Atkinson E.G. \& Wacasey J.W. 1989. Benthic invertebrates collected from the western Canadian Arctic, 1951 to 1985. Canadian Data Report of Fisheries and Aquatic Sciences 745. Winnipeg: Department of Fisheries and the Environment, Fisheries and Marine Service. 
Barber D.G. \& Massom R.A. 2007. The role of sea ice in bipolar polynya processes. In W.O. Smith Jr. \& D.G. Barber (eds.): Polynyas: windows into polar oceans. Pp. 1-43.

Amsterdam: Elsevier.

Barrett R.T., Bakken V. \& Krasnov J.V. 1997. The diets of common and Brünnich's guillemots Uria aalge and $U$. lomvia in the Barents Sea region. Polar Research 16, 73-84.

Berry S.S. 1925. The cephalopoda collected by the Canadian Arctic Expedition, 1913-18. Report of the Canadian Arctic Expedition 1913-18 8B, 3-8.

Bjørke H. 2001. Predators of the squid Gonatus fabricii (Lichtenstein) in the Norwegian Sea. Fisheries Research 52, 113-120.

Brown R.G.B. \& Nettleship D.N. 1981. The biological significance of polynyas to Arctic colonial seabirds. In I. Stirling et al. (eds): Polynyas in the Canadian Arctic. Canadian Wildlife Service Occasional Paper 45. Pp. 59-65. Ottawa: Canadian Wildlife Service.

Chambers C.A. \& Dick T.A. 2007. Using environmental variables to predict the structure of deep-sea Arctic fish communities: implications for food web construction. Arctic, Antarctic and Alpine Research 39, 2-8.

Cephbase. National Resource Center for Cephalopods, Galveston, TX. Online database accessed on the internet at http://www.cephbase.utmb.edu/ in December 2007.

Clarke M.R. 1966. A review of the systematics and ecology of oceanic squids. Advances in Marine Biology 4, 91-300.

Collins M.A. 2002. Cirrate octopods from Greenland and Iceland waters. Journal of the Marine Biological Association of the United Kingdom 82, 1035-1036.

Collins M.A. 2005. Opisthoteuthis borealis: a new species of cirrate octopod from Greenland waters. Journal of the Marine Biological Association of the United Kingdom 85, 1475-1479.

COSEWIC (Committee on the Status of Endangered Wildlife in Canada) 2004. COSEWIC assessment and update status report on the Monodon monoceros in Canada. Ottawa: Committee on the Status of Endangered Wildlife in Canada.

Dahl T.M., Lydersen C., Kovacs K.M., Falk-Petersen S., Sargent J., Gjertz I. \& Gulliksen B. 2000. Fatty acid composition of the blubber in white whales (Delphinapterus leucas). Polar Biology 23, 401-409.

Dawe E.G., Bowering W.R. \& Joy J.B. 1998. Predominance of squid (Gonatus spp.) in the diet of Greenland halibut (Reinhardtius hippoglossoides) on the deep slope of the northeast Newfoundland continental shelf. Fisheries Research 36, 267-273.

Dehn L.-A., Sheffield G.G., Follmann E.H., Duffy L.K., Thomas D.L. \& O'Hara R.M. 2007. Feeding ecology of phocid seals and some walrus in the Alaskan and Canadian Arctic as determined by stomach contents and stable isotope analysis. Polar Biology 30, 167-181.

Dommasnes A., Christensen V., Ellertsen B., Kvamme C., Melle W., Nøttestad L., Pedersen T., Tjelmeland S. \& Zeller D. 2001. An Ecopath model for the Norwegian Sea and
Barents Sea. In S. Guénette et al. (eds.): Fisheries impacts on North Atlantic ecosystems: models and analyses. Fisheries Centre Research 9, 213-240.

Finley K.J. \& Evans C.R. 1983. Summer diet of the Bearded seal (Erignathus barbatus) in the Canadian High Arctic. Arctic 36, 82-89.

Finley K.J. \& Gibb E.J. 1982. Summer diet of the narwhal (Monodon monoceros) in Pond Inlet, northern Baffin Island. Canadian Journal of Zoology 60, 3353-3363.

Frandsen R.P. \& Wieland K. 2004. Cephalopods in Greenland waters. Technical Report 57. Pinngortitaleriffik: Greenland Institute of Natural Resources.

Gaston A.J. 1985. The diet of thick-billed murre chicks in the eastern Canadian Arctic. The Auk 102, 727-734.

GeoNames. Online database accessed on the internet at http://www.geonames.org in December 2007.

Grimpe G. 1933. Die cephalopodan des arktischen Gebietes. (Cephalopods of the Arctic.) Fauna Arctica 6, 491-514.

Haug R., Nilssen K.T. \& Lindblom L. 2004. Feeding habits of harp and hooded seals in drift ice waters along the east coast of Greenland in summer and winter. Polar Research $23,35-42$.

Hay K.A. \& Mansfield A.W. 1989. Narwhal, Monodon monoceros Linnaeus 1758. In S.H. Ridgeway \& R.J. Harrison (eds.): Handbook of marine mammals. Vol. 4. River dolphins and the larger toothed whales. Pp. 145-176. London: Academic Press.

Historical Benthic Dredge Samples from the Southern Baltic and the North Sea. Online database accessed through Global Biodiversity Information Facility (GBIF) Data Portal at http://data.gbif/org/datasets/resource/407 on 5 November 2007.

Hjort J. \& Ruud J.T. 1929. Whaling and fishing in the North Atlantic. In J. Hjort \& J.T. Ruud: Whales and plankton in the North Atlantic. A contribution to the work of the Whaling Committee and of the North Eastern Area Committee. Rapports et Procès-Verbaux des Réunions Conseil Permanent International Pour L'Exploration de la Mer 56. Pp. 1-123. Copenhagen: Conseil Permanent International pour l'Exploration de la Mer.

Hooker S.K., Iverson S.J., Ostrom P. \& Smith S.C. 2001. Diet of northern bottlenose whales inferred from fatty-acid and stable isotope analyses of biopsy samples. Canadian Journal of Zoology 79, 1442-1454.

Ifremer BIOCEAN, Deep Sea Benthic Fauna. Online database accessed through Global Biodiversity Information Facility (GBIF) Data Portal at http://data.gbif.org/datasets/ resource/358 on 5 November 2007.

Integrated Taxonomic Information System. Accessed on the internet at http://www.itis.gov/ in 2008.

Kondakov N.N. 1937. Golovonogie molljuski (Cephalopoda) Karskogo morja. (The Cephalopoda of the Kara Sea.) Transactions of the Arctic Institute 1, 61-67.

Kristensen T.K. 1977. Hatching, growth, and distribution of juvenile Gonatus fabricii (Mollusca: Cephalopoda) in Greenland waters. Astarte 10, 21-28. 
Kristensen T.K. 1982. Multivariate statistical analysis of geographic variation in the squid Gonatus fabricii (Lichtenstein, 1818) (Mollusca: Cephalopoda). Malacologia $22,581-586$.

Kristensen T.K. 1983. Gonatus fabricii. In P.R. Boyle (ed.): Cephalopod life cycles. Vol. 1. Species accounts. Pp. 159-173. London: Academic Press.

Laidre K.L., Heide-Jørgensen M.P., Jørgensen O.A. \& Treble M.A. 2004. Deep-ocean predation by a High Arctic cetacean. ICES Journal of Marine Science 61, 430-440.

Loeng H., Brander K., Carmack E., Denisenko S., Drinkwater K., Hansen B., Kovacs K., Livingston P., McLaughlin F. \& Sakshaug E. 2005. Marine systems. In C. Symon et al. (eds.): Arctic climate impact assessment. Pp. 439-538. Cambridge: Cambridge University Press.

Lowry L.F., Frost K.J. \& Seaman G.A. 1986. Investigations of belukha whales in coastal waters of western and northern Alaska, III: food habits. Fairbanks: Alaska Department of Fish and Game.

Mallory M.L. \& Gilchrist H.G. 2005. Marine birds of the Hell Gate polynya, Nunavut, Canada. Polar Research 24, 87-93.

Mercer M.C. 1968. A synopsis of the recent Cephalopoda of Canada. In: Proceedings of the Symposium on Mollusca held at Cochin from January 12 to 16, 1968. Part I. Marine Biological Association of India Symposium Series 3. Pp. 265-276. Madapam: Marine Biological Association of India.

Michel C., Ingram R.G. \& Harris L.R. 2006. Variability in oceanographic and ecological processes in the Canadian Arctic Archipelago. Progress in Oceanography 71, 379-401.

Muus B.J. 1962. Cephalopoda. The Godthaab Expedition 1928. Meddelelser om Gronland 81(5). Copenhagen: Committee on Scientific Research in Greenland.

Muus B.J. 2002. The Bathypolypus-Benthoctopus problem of the North Atlantic (Octopodidae, Cephalopoda). Malacologia 44, 175-222.

Nesis K.N. 1965. The distribution and nutrition of young squid Gonatus fabricii (Licht.) in the Labrador Sea and the Norwegian Sea. Oceanology 5, 102-108.

Nesis K.N. 1987. Golovonogie molljuski Severnogo Ledovitogo okeana i ego morej. (Cephalopod molluscs of the Arctic Ocean and its seas.) In A.I. Kafanov (ed.): Fauna i raspredelenie molljuskov: Severnaja Pacifika i Poljarnyj Bassejn. (Fauna and distribution of molluscs: North Pacific and Arctic Basin.) Pp. 115-136. Vladivostok: Far Eastern Scientific Center of the USSR Academy of Sciences.

Nesis K.N. 2001.West-Arctic and east-Arctic distributional ranges of cephalopods. Sarsia 86, 1-11.

Nesis K.N. 2003 (1971). Squid Gonatus fabricii (Licht.) in the center of the Arctic Ocean. In M.J. Sweeney (ed.): English translations of selected publications on cephalopods by Kir $N$. Nesis. Vol. 1. Part 1. Pp. 71-85. Washington, D.C.: Smithsonian Institution Libraries.

Nesis K.N. 2003 (1989). Cephalopods from open waters of the Okhotsk Sea: general distribution and zoogeography. In M.J. Sweeney (ed.): English translations of selected publications on cephalopods by Kir N. Nesis. Vol. 1. Part 2.
763-772. Washington, D.C.: Smithsonian Institution Libraries.

Nesis K.N., Amelekhina A.M., Boltachev A.R. \& Shevtsov G.A. 2003 (1985). Records of giant squid of the genus Architeuthis in the north Pacific and south Atlantic. In M.J. Sweeney (ed.): English translations of selected publications on cephalopods by Kir N. Nesis. Vol. 1. Part 2. Pp. 685-697. Washington, D.C.: Smithsonian Institution Libraries.

North Pacific Groundfish Observer. Online database accessed through Global Biodiversity Information Facility (GBIF) Data Portal at http://data.gbif.org/datasets/resource/331 on 5 November 2007.

O'Dor R. 1983. Illex illecebrosus. In P.R. Boyle (ed.): Cephalopod life cycles. Vol. 1. Species accounts. Pp. 175-199. London: Academic Press.

O'Dor R. \& Macalaster E. 1983. Bathypolypus arcticus. In P.R. Boyle (ed.): Cephalopod life cycles. Vol. 1. Species accounts. Pp. 401-410. London: Academic Press.

Orr D.C. \& Bowering W.R. 1997. A multivariate analysis of food and feeding trends among Greenland halibut (Reinhardtius hippoglossoides) sampled in Davis Strait, during 1986. ICES Journal of Marine Science 54, 819-829.

Perez M.A. 1990. Review of marine mammal population and prey information for Bering Sea ecosystem studies. NOAA Technical Memorandum NMFS F/NWC-186. Washington, D.C.: US Department of Commerce.

Piatkowski U. \& Wieland K. 1993. The Boreoatlantic gonate squid Gonatus fabricii: distribution and size off West Greenland in summer 1989 and in summer and autumn 1990. Aquatic Living Resource 6, 109-114.

Portner H.-O. \& Farrel A.P. 2008. Physiology and climate change. Science 322, 690-692.

Raskoff K.A., Hopcroft R.R., Kosobokova K.N., Purcell J.E \& Youngbluth M.J. In press. Jellies under ice: ROV observations from the Arctic 2005 Hidden Ocean Expedition. Deep-Sea Research II.

Santos M.B., Clarke M.R. \& Pierce G.J. 2001. Assessing the importance of cephalopods in the diets of marine mammals and other top predators: problems and solutions. Fisheries Research 52, 121-139.

Sennikov A.M., Mukhin S.G. \& Bliznichenko T.E. 1989. Distribution and trophic importance of juvenile squid (Gonatus fabricii Lichtenstein) in the Norwegian and Barents seas in 1986-1988. ICES CM 1989/K: 15. Copenhagen: International Council for the Exploration of the Sea.

Smithsonian National Museum of Natural History Invertebrate Zoology Collections. Online database accessed through Global Biodiversity Information Facility (GBIF) Data Portal at http://data.gbif.org/datasets/resource/1834 on 22 May 2008.

Stewart D.B., Ratynski R.A., Bernier L.M.J. \& Ramsey D.J. 1993. A fishery development strategy for the Canadian Beaufort Sea-Amundsen Gulf Area. Canadian Technical Report of Fisheries and Aquatic Sciences 1910. Winnipeg: Department of Fisheries and Oceans.

Stewart B.E. \& Stewart E.A. 1989. Delphinapterus leucas. Mammalian Species 336. American Society of Mammalogists. 
Swedish Museum of Natural History: Invertebrates. Online database accessed through Global Biodiversity Information Facility (GBIF) Data Portal at http://data.gbif.org/datasets/ resource/1027 on 5 November 2007.

Sweeney M.J., Roper C.F.E., Mangold K.M., Clarke M.R. \& Boletzky S.V. (eds.) 1992. "Larval" and juvenile cephalopods: a manual for their identification. Smithsonian Contributions to Zoology 513. Washington, D.C.: Smithsonian Institution Press.

Taxonomic Information System for the Belgian Coastal Area. Online database accessed through Global Biodiversity Information Facility (GBIF) Data Portal at http:// data.gbif.org/datasets/resource/361 on 22 May 2008.

Tomilin A.G. 1967 (1957). Mammals of the U.S.S.R. and adjacent countries. Vol. 9. Cetacea. Jerusalem: Israel Program for Scientific Translations.

Treble M.A. 2007. Analysis of data from the 2006 trawl surveys of NAFO division OA. Scientific Council Meeting. NAFO SCR Doc. 07/41. Dartmouth, NS: Northwest Atlantic Fisheries Organization.

Wacasey J.W., Atkinson E.G. \& Glasspoole L. 1979. Zoobenthos data from Upper Frobisher Bay 1967-1973. Canadian Data Report on Fisheries and Aquatic Science 64. Ste. Anne de Bellevue, QC: Department of Fisheries and Oceans.

Welch H.E., Bergmann M.A., Siferd T.D., Martin K.A., Curtis M.F., Crawford R.E., Conover R.J. \& Hop H. 1992. Energy flow through the marine ecosystem of the Lancaster Sound region, Arctic Canada. Arctic 45, 343-357.

WHOI (Woods Hole Oceanographic Institution) 2006. Polar discovery. Arctic Ocean circulation. Accessed on the internet at http://polardiscovery.whoi.edu/arctic/ circulation.html on 7 January 2008.

Wiborg K.F., Gjøsæeter J. \& Beck I.M. 1982. The squid Gonatus fabricii: investigations in the Norwegian Sea and western Barents Sea. ICES CM 1984/K: 19. Copenhagen: International Council for the Exploration of the Sea.

Woll A.K. \& Gundersen A.C. 2004. Diet composition and intra-specific competition of young Greenland halibut around southern Greenland. Journal of Sea Research 51, 243-249.

Wood J.B. 2000. The natural history of Bathypolypus arcticus (Prosch), a deep-sea octopus. PhD thesis, Dalhousie University.

Young R.E 1973. Evidence for spawning by Gonatus sp. (Cephalopoda: Teuthoidea) in the High Arctic ocean. Nautilus 87, 53-58.

Zumholz K. \& Frandsen R.P. 2006. New information on the life history of cephalopods off west Greenland. Polar Biology 29, 169-178.

Zumholz K., Klügel A., Hansteen T. \& Piatkowski U. 2007. Statolith microchemistry traces of the environmental history of the Boreoatlantic Armhook squid Gonatus fabricii. Marine Ecology Progress Series 333, 195-204. 